\title{
ILLYRIAN PRE-ALPINE FIR AND BEECH FORESTS - THE ASSOCIATION HOMOGYNO SYLVESTRIS- FAGETUM MARINČEK ET AL. 1993
}

\author{
Lojze MARINČEK* \& Andraž ČARNI**
}

\begin{abstract}
The work deals with the association Homogyno sylvestris-Fagetum in the pre-Alpine region of Slovenia. The communitis were classified into a geographical race typica and divided into six subassociations: typicum subass. nova, mercurialetosum perennis subass. nova, festucetosum altissimae subass. nova, calamagrostietosum variae subass. nova, luzuletosum sylvaticae subass. nova and vaccinietosum myrtilli subass. nova. The results are shown in the analytical table, as well as in two diagrams.

Key words: Fagus sylvatica, Abies alba, forests, pre-Alpine region, forest community, vegetation, Slovenia.

Izvleček

$\mathrm{V}$ članku je predstavljena asociacija Homogyno sylvestris-Fagetum v predalpskem fitogeografskem območju. Združba je uvrščena v geografsko varianto typica in členjena v šest subasociacij: typicum subass. nova, mercurialetosum perennis subass. nova, festucetosum altissimae subass. nova, calamagrostietosum variae subass. nova, luzuletosum sylvaticae subass. nova in vaccinietosum myrtilli subass. nova. Rezultati so predstavljeni $\mathrm{z}$ analitsko tabelo in dvema diagramoma.
\end{abstract}

Ključne besede: Fagus sylvatica, Abies alba, gozdovi, predalpsko območje, gozdna združba, vegetacija, Slovenija.

\section{INTRODUCTION}

In comparison with Dinaric fir and beech stands of the association Omphalodo-Fagetum, thoroughly studied in terms of the phytosociology and ecology by a number of researchers (e.g. Horvat 1938, M. Wraber 1960, Tregubov et al. 1957, Puncer 1979, 1980, Puncer, Wojterski \& Zupančič 1974, Horvat, et al. 1974, Marinček 1987, Kordiš 1993, Dakskobler et al. 2000, Franjić et al. 2001, Surina 2001, 2002) there exist only some elaborations of the pre-Alpine fir and beech forests (Marinček 1973a, 1973b, 1978, Dakskobler 2002, 2002a, 2002b, 2004). However, numerous detailed reports have been made for forest praxis including rele- vant phytosociological maps in a scale of $1: 10000$ with descriptions of different subassociations and also with detailed pedologic analyses, but they were not published. Besides, some additional studies were required which should have highlighted the floristic particularity of the pre-Alpine beech forests of the Illyrian floral province, either from the fir and beech forests of the utmost part of the Dinaric mountains showing a transitional character between Dinaric and pre-Alpine fir and beech forests, or from the association Anemono-Fagetum, frequently bordering on the forests of the association Homogyno sylvestris-Fagetum.

The long-term phytosociological research of the pre-Alpine beech forests is also reflected in

\footnotetext{
* Pugljeva 27, SI-1000 Ljubljana

** Institute of Biology, Scientific Research Centre of the Slovenian Academy of Sciences and Arts, Novi trg 2, p.b. 306, SI-1001 Ljubljana.
} 
their synsystematics. They were first named by M. Wraber (1960) as Abieti-Fagetum austroalpinum M. Wraber 1960. Robič renamed them as AbietiFagetum praealpino-dinaricum Robič 1965 (Košir et al. 1968). A few years later, when the designation of a zonal association according to phytogeographical territories won wide recognition, they were renamed as Abieti-Fagetum praealpinum Marinček 1973 (Marinček 1973b). Not earlier than in 1993 (Marinček, Mucina, Zupančič, Dakskobler et Accetto 1993), the binomial designation on a strictly floristic basis prevailed (see Barkman et al. 1986, but also Weber et al. 2000). At that time the preAlpine fir and beech forests acquired their present name Homogyno sylvestris-Fagetum Marinček et al. 1993.

In the area of Southeastern Alps three geographical races were described: Homogyno sylvestris-Fagetum var. geogr. Luzula nivea Marinček ex Dakskobler 2002 (Dakskobler 2002), Homogyno sylvestris-Fagetum var. geogr. Sesleria autumnalis Dakskobler 2002 (Dakskobler 2002a), Homogyno sylvestris-Fagetum var. geogr. Scopolia carniolica Dakskobler 2002 (Dakskobler 2002b). In the region of Savinjske Alpe and Kamniške Alpe appears a new geographical race Homogyno sylvestris-Fagetum var. geogr. typica var. geogr. nova presented in this paper.

\section{METHODS}

The vegetation was sampled in the pre-Alpine region of Slovenia and then processed by using the standard Central European method (Braun-Blanquet 1964). The numerical analysis has been made by SYN-TAX program, principal co-ordinate analysis, using similarity ratio as a measure of similarity (Podani 2001). The Braun-Blanquet scale was transformed as proposed by van der Maarel (1979). The nomenclature of plant species is according to Ehrendorfer (1973) for Cormophyta, Martinčič (2003) for Bryopsida, Frey et al. (1995) for Hepaticae and Wirth (1995) for Lichenes. The names of syntaxa are according to the Nomenclatural revision of Aremonio-Fagion (Marinček et al. 1993). As far as the floristic comparison is concerned, no moss species have been taken into consideration; these are, however, stated in the tables of the described subassociations of the association Homogyno sylvestris-Fagetum. Individual researchers do not record them, or else they are generally not familiar with them. Most of the moss species have a cosmopoli- tan nature and their diagnostical value, particularly in zonal communities, is negligible. The synsystematic spectrum (Fig. 2) was made on the basis of a comparative synthetic table using the presence in percentage as ponder.

\section{GENERAL ECOLOGICAL CONDITIONS}

The association Homogyno sylvestris-Fagetum is a zonal association of the pre-Alpine phytogeographical territory of the Illyrian floral province (Marinček 1995). Its stands thrive at all aspects and are most frequently found in large continuous areas at an altitude of 800 to 1000 metres above sea level. In some sites, exposed to the sun, they reach up to 1400 metres, whereas on very shady slopes they thrive down to an altitude of 500 metres. In the area of the pre-Alpine phytogeographical territory, a humid climate with fresh summers and cold winters prevails. The most precipitation rich area is the western part of the region under consideration, where the average annual rainfall exceeds $2300 \mathrm{~mm}$. The precipitation regime is favourable. The precipitation reduces progressively towards the east, however the average annual rainfall is still more than $1500 \mathrm{~mm}$.

The data for the period 1961-1990 for the meteorological station Zgornje Jezersko, which is located in the middle of the area of distribution of the association Homogyno-Fagetum, show that the mean annual precipitations are $1976 \mathrm{~mm}$ and they are equally distributed through the year. The cold winter period lasting from December to February is characteristic of the thermal conditions of the pre-Alpine region, particularly in the mountain region (Zgornje Jezersko the minimal temperature ranges from -5.6 to $-7.3{ }^{\circ} \mathrm{C}$ ). The average monthly temperature in summer months is relatively high (ranging from 7.6 to $9.3^{\circ} \mathrm{C}$ ). The extreme temperatures are very pronounced, particularly in the valleys where temperature inversion occurs very frequently (for example the valley of Logarska dolina). The area is covered by snow for approx. 106 days. (Mekinda-Majaron 1995, Zupančič 1995, Ovsenik-Jeglič 2000).

More gentle relief in terms of smooth slopes which gradually proceed to rounded mountain ridges is developed on the mixed calcareous and noncalcareous bedrock. Deep ditches are cut into the slopes providing constant running water. By contrast, a diverse relief is developed on the 
calcareous bedrock. There are fragments of karstic land configuration on limestones. Furthermore, the plain surfaces are combined with sinkholes and rock slopes and precipice walls in a mosaic form. The slopes are steep and smooth with pointed summits on dolomites, but also remnants of glacier moraines where water piles up calcareous loose rocks on the bottom of pre-Alpine valleys.

The geologic bedrock is well diversified. Among the calcareous ground stones, there are predominantly triassic dolomites, dolomite limestones and dachstein limestones. Noncalcareous stones consist of clay schists and sandstones. (Seidl 1907-1908)

Due to the varied bedrock composition and diversified land configuration there are numerous types of soils which are mutually combined in a mosaic form. The most developed soils within the calcareous bedrock - such as Chromic Cambisol, deep Chromic Luvisol - are on Dachstein limestones and on the mixed calcareous and noncalcareous bedrock. More initial soil forms are particularly found on dolomites: Rendzina of different development stages from Protorendzina to Chromic Rendzina and shallow skeletal chromic soils. The soil is less developed also at higher altitudes, on lime loose rocks or on remnants of glacier moraines at the bottom of Alpine valleys.

Stands of the association thrive in the pre-Alpine phytogeographical territory of the Illyrian floral province. In the floristic and vegetational aspect of the syntaxa, the Illyrian pre-Alpine territory has a certain transitional feature among the clearly Illyrian syntaxa of the pre-Dinaric and Dinaric phytogeographical region and those from the south-Alpine region on the border with the Central European floral province. This results in a certain floristic impoverishment of zonal associations bordering the association Homogyno sylvestris-Fagetum: Anemono-Fagetum var. geogr. Helleborus niger, Lamio orvalae-Fagetum var. geogr. Dentaria pentaphyllos, Ranunculo platanifolii-Fagetum var. geogr. Hepatica nobilis, Polysticho lonchitis-Fagetum var. geogr. Salix waldsteiniana as well as azonal associations like Ostryo-Fagetum, particularly in the sense of scarce presence of certain character and differential species of the alliance Aremonio-Fagion. However, this is not indicated to such an extent that the authors of the revision of the nomenclature of the Illyrian beech forests (Marinček et al. 1993) would hesitate to classify these associations and the association Homogyno-Fagetum into the alliance of the Illyrian beech forests.

\section{STRATIFICATION OF THE COMMU- NITY, SOCIOLOGICAL STRUCTURE AND FLORISTIC COMPOSITION}

In well preserved forests, Fagus sylvatica, Abies alba and Picea abies prevail in the tree layer. With regard to the very diverse site conditions of the stands, they rarely function as a biologically and ecologically equivalent edifier with regard to their nature. Therefore, beech and fir alternately prevail. More significant consequences for their proportion are caused by unsuitable human activities carried out by farmers, especially in the past. Intensive felling of fir trees accelerates the growth of beech and spruce trees which were planted on certain sites in larger areas. Selection forest management, which takes place rarely, is the most suitable way of cutting those forests.

In some places, pre-Alpine fir-beech stands are mixed with Acer pseudoplatanus. However, in comparison to Dinaric fir-beech stands (OmphalodoFagetum), they are not so frequently present. Ulmus glabra is found very scarcely. Larix decidua appears individually at higher altitudes. Ostrya carpinifolia is an expressively thermophilic and a lit-up tree appearing individually in the area of pre-Alpine fir and beech forests only on very sunny mountain ridges. Fraxinus excelsior is found only in Alpine valleys in special microclimatic conditions. The shrub layer is not well developed. Mainly, it is composed of the predominating tree species: beech, fir and spruce. In the shrub layer, the following species occur more or less regularly: Daphne mezereum, Lonicera alpigena, Rubus idaeus, Lonicera nigra and Clematis alpina. Shrubs with a moderately thermophilic character, like Clematis vitalba, are very seldom.

The herb layer is relatively well developed. With regard to the season, the herbs cover from 40 to 90 percent of the ground surface area. Among sociological and ecological groups, the species of beech forests predominate, particularly Lamiastrum montanum and L. flavidum, Prenanthes purpurea, Mycelis muralis, Salvia glutinosa, Polystichum aculeatum, Euphorbia amygdaloides, Paris quadrifolia, Actaea spicata, Viola reichenbachiana and some others.

Special diagnostic importance is given to differential species of the alliance Aremonio-Fagion. They occur more or less constantly. These are Aposeris foetida, Aremonia agrimonoides, Cardamine trifolia, Cyclamen purpurascens, Dentaria enneaphyllos (its somewhat smaller cover results from certain autumn samplings) and Homogyne sylvestris. 
Other character species of the alliance AremonioFagion are Calamintha grandiflora, Omphalodes verna and Rhamnus fallax. They appear rarely at the border of their distribution areas as accidental species. Moreover, Vicia oroboides and Knautia drymeia subsp. drymeia appear also very rarely, while Lamium orvala appears more frequently at lower altitudes.

The species of the order Adenostyletalia are present constantly and abundantly in compliance with the altimontane character of the association Homogyno-Fagetum like Polygonatum verticillatum, Adenostyles glabra, Ranunculus platanifolius, Saxifraga rotundifolia, Dryopteris filix-mas, Athyrium filix-femina, Senecio fuchsii and Veratrum album. Among them there are differential species of the suballiance Saxifrago-Fagenion that are well represented and give the association a typical altimontane character.

The character species of the class Querco-Fagetea appear less frequently in compliance with the cold region where the association grows. The most frequent are Anemone nemorosa and Carex digitata. Ajuga reptans and Galium laevigatum are less frequent. The other species appear sporadically.

An important group is represented with slightly to moderately acidophilic species of the class Vaccinio-Piceetea, like: Oxalis acetosella, Veronica urticifolia, Gentiana asclepiadea, Rosa pendulina, Luzula luzuloides, Hieracium sylvaticum, Vaccinium myrtillus, Maianthemum bifolium and Valeriana tripteris which result from the colder and humid climate. Consequently, there is also predominantly well-rotted humus. Strong acidophilic species like Lycopodium annotinum, Huperzia selago, Vaccinium vitis-idaea, Homogyne alpina, Luzula sylvatica and some others thrive only in peculiar ecological conditions, at higher altitudes and in frost pockets. Other less frequent species have not been classified to the sociological units, such as Calamagrostis varia, Carex alba, Sorbus aucuparia, Asplenium viride and Fragaria vesca.

The moss layer is well developed only on certain sites. Sometimes it is even not present at all in the relevés. Among the moss species Ctenidium molluscum, Isothecium alopecuroides, Plagiochila asplenioides, Fissidens taxifolius and Neckera crispa dominate.

\section{CHARACTER SPECIES AND DIFFEREN- TIAL SPECIES OF THE COMMUNITY}

The only, but weak, character species of the association Homogyno-Fagetum is Homogyne sylvestris. According to Praprotnik (1987), the Alpine-Illyrian floral element is spread in the South-eastern Calcareous
Alps and their bordering areas, and in the area of the Illyrian floral province. Borhidi (1963) considers it as the first quality character species of the alliance Aremonio-Fagion. Although various authors have made slightly different diagnoses of the area of distribution, they have an opinion similar to that of Borhidi, who considers it to be a typical Illyrian species of the montane belt. Although the species Homogyne sylvestris builds special subassociations in the Dinaric fir and beech forests (Omphalodo-Fagetum homogynetosum) as well as in altimontane beech forests (Anemono-Fagetum var. geogr. Helleborus niger homogynetosum, Ranunculo platanifolii-Fagetum var. geogr. Hepatica nobilis homogynetosum), it defines very well the association Homogyno sylvestris-Fagetum as the Illyrian fir and beech community. It clearly distinguishes the latter from similar communities of the alliance Eu-Fagion (particularly Helleboro nigri-Fagetum Zukrigl 1974) (Zukrigl 1989).

The differential species of the association $\mathrm{Ho}^{-}$ mogyno sylvestris-Fagetum are composed of two ecological and sociological groups.

The first one comprises the species of the suballiance of altimontane beech forests of the Illyrian floral province Saxifrago-Fagenion: Polygonatum verticillatum, Adenostyles glabra, Ranunculus platanifolius, Saxifraga rotundifolia and Luzula sylvatica appear more abundantly. The others, such as Cicerbita alpina, Geranium sylvaticum, Polystichum lonchitis appear more rarely. Within this group, there are species which are not considered by the authors as differential species of the suballiance Saxifrago-Fagenion like Clematis alpina, Calamagrostis villosa and Homogyne alpina.

The second differential species group consists of moderately acidophilic species which generally reach a very high constancy: Veronica urticifolia, Luzula luzuloides, Gentiana asclepiadea, Vaccinium myrtillus and some others. A diagnostically very important differential species is also Larix decidua, although it is found only at upper altitudes and gives the association a dealpine character.

Dakskobler (2002a) enumerates among differential species also the species Asplenium viride and Saxifraga cuneifolia and in a wider sense also Laburnum alpinum and Anemone trifolia.

\section{SYNSYSTEMATICS OF THE ASSOCIATION}

This paper deals with a new geographical race $\mathrm{Ho}^{-}$ mogyno sylvestris-Fagetum var. geogr. typica that is divided into six subassociations and several variants. 
Homogyno sylvestris-Fagetum var. geogr. typica typicum subass. nova hoc loco represents an ecological and floristical average of the association. It thrives in all expositions on gently inclined slopes and plateaus. The bedrock is composed of limestones, particularly Dachstein limestone, Dolomite limestones and more seldom dolomites.

In some places these stands also thrive on mixed calcareous and noncalcareous bedrock. In such cases the noncalcareous bedrock, which consists mainly of schists and sandstones of different geological ages, is filled with lime and calcareous loose rocks.

A well diversified bedrock in connection with very diverse relief results in many soil forms. There are shallow Chromic Cambisol and Rendzina of various development stages on dolomite limestones, particularly on steeper slopes and mountain ridges. On limestones, there is most frequently medium deep to deep Chromic Cambisol with very pronounced surface ground rock cover in some places. There is also Chromic Cambisol which is very fertile due to a favourable mixture of chemical and physical properties on the mixed calcareous and noncalcareous bedrock. The subassociation typicum has no pronounced differential species. Favourable growing conditions are indicated by the presence of ecologically more demanding plants, particularly of the species of beech forests.

The holotypus of the subassociation is relevé no. 4, Table no. 1, holotypus hoc loco.

Two variants were defined within the framework of the subassociation.

Homogyno sylvestris-Fagetum var. geogr. typica typicum var. Hacquetia epipactis var. nova hoc loco

It encompasses small areas at the lower edge of the area of distribution of the association Homogyno sylvestris-Fagetum. It appears below 1000 metres above sea level on gently inclined sunny slopes above limestone in medium deep Chromic Cambisol. In addition to the species Hacquetia epipactis which appears abundantly, there are differential species of the class Querco-Fagetea: Rosa arvensis, Crataegus monogyna, Helleborus odorus and Primula vulgaris, the species of the alliance Erythronio-Carpinion. All the above mentioned species show a certain similarity to the association Hacquetio-Fagetum.

The holotypus of the variant is relevé no. 1, Table no. 1.

Homogyno sylvestris-Fagetum var. geogr. typica typicum var. Gymnocarpium dryopteris var. nova hoc loco
The variant depends on edaphic factors. It grows on the mixed calcareous and noncalcareous bedrock in deep calcareous Chromic Luvisol, which is very fertile due to a favourable mixture of chemical and physical properties. The differential species of the variant are Gymnocarpium dryopteris, Dryopteris carthusiana agg. and Lonicera nigra indicating more acid soil.

The holotypus of the variant is relevé no. 16, Table no. 1 .

Homogyno sylvestris-Fagetum var. geogr. typica calamagrostietosum variae subass. nova hoc loco

This appears on sunny, deep and very stony slopes. It is often found in narrow strips along steep mountain ridges. On limestones, Dolomite limestones and dolomites, predominantly of Triassic age, there is Rendzina of different development stages from very shallow to medium deep, passing over to shallow Chromic Cambisol.

The differential species of the subassociation are Calamagrostis varia and Carex alba. The first one grows abundantly in lit-through forests on steep rock slopes, whereas Carex alba reaches its optimal site conditions on skeletal shallow soils prevailing in the subassociation described below. The subassociation is in a certain sense similar to the vicariant subassociation mercurialetosum. Both dispose of very similar ecological conditions, i.e. deep stony sunny slopes, less developed soils. The difference is in the fact that the subassociation calamagrostietosum variae grows at higher altitudes at the edge of the area of distribution of the Illyrian floral province. Its floristic composition differs sufficiently from the subassociation mercurialetosum.

The holotypus of the subassociation is relevé no. 19, Table no. 1, holotypus hoc loco.

Homogyno sylvestris-Fagetum var. geogr. typica mercurialetosum perennis subass. nova hoc loco

It grows at relatively lower elevations above sea level ranging from 750 to around 1050 metres, on steep to very steep shady slopes and frequently on rocky mountain ridges. There is a complex of different Rendzina and very skeletal Chromic Cambisol on limestones and dolomite limestones and dolomites. In the upper layers there is well-rotted and raw humus as a consequence of very shady sites.

The differential species of the subassociation is Mercurialis perennis which grows optimally on skeletal soils with good drainage.

The character species Homogyne sylvestris is well represented with a considerable cover in places. 
The holotypus of the subassociation is relevé no. 29, Table no. 1, holotypus hoc loco.

The subassociation has been divided into two variants.

Homogyno sylvestris-Fagetum var. geogr. typica mercurialetosum perennis var. Cephalanthera damasonium var. nova hoc loco

It grows mainly on the limestone bedrock in medium deep skeletal Chromic Cambisol where well-rotted humus predominates. The differential species of the variant are Cephalanthera damasonium, Salvia glutinosa and Polygonatum multiflorum. This variant is differentiated by the almost complete absence of acidophilic species.

The holotypus of the variant is relevé no. 24, Table no. 1 .

Homogyno sylvestris-Fagetum var. geogr. typica mercurialetosum perennis var. Homogyne sylvestris var. nova hoc loco

It is limited to expressively shady steep stone slopes where there is horizontal well-rotted and raw humus in the upper soil layers.

There are Ostrya carpinifolia and Larix decidua in the tree layer. The appearance of two ecologically different species on the same site can be explained by rocky ridges where the light conditions facilitate the growth of both heliophilic species.

The differential species of the variant are Homogyne sylvestris and Neckera crispa. The variant is distinguished by the permanent presence of moderately acidophilic species Valeriana tripteris, Gentiana asclepiade $a$ and some others.

The holotypus of the variant is relevé no. 29, Table no. 1 .

Homogyno sylvestris-Fagetum var. geogr. typica festucetosum altissimae subass. nova hoc loco

It grows on rather steep and rocky, often shady slopes in a step-resembling form, with rounded summits and ridges. The bedrock consists mainly of Dachstein limestone, on which there is a soil complex of well-rotted and decayed humus. At higher elevations, well-rotted humus and Chromic Luvisol predominate. On rocks and stones under the turf of the grass Festuca altissima there is wellrotted Rendzina, whereas in crevasses and pockets between stones there is Chromic Luvisol.

The differential species of the subassociation is Festuca altissima, which grows optimally on medium deep rocky and moderately acidic soils with wellrotted humus, principally on cold sites, reflects very well the site conditions.
The differential species of the suballiance Saxifrago-Fagenion are well represented by Polygonatum verticillatum, Adenostyles glabra, Luzula sylvatica and Ranunculus platanifolius. The remaining ones are only accidental species.

The presence of the species of the alliance Aremonio-Fagion is rather poor. More common are only Dentaria enneaphyllos, Cyclamen purpurascens, Aremonia agrimonoides and Helleborus niger subsp. niger. Species of the order Fagetalia sylvaticae, which are well represented with high coverage value, in some sites show favourable site conditions of the described subassociation.

The share of acidophilic species rises considerably with increasing altitude. The species with high coverage value are Picea abies, Oxalis acetosella, Luzula sylvatica and some others.

The holotypus of the subassociation is relevé no. 40, Table no. 1, holotypus hoc loco.

The subassociation is divided into one variant and two forms.

Homogyno sylvestris-Fagetum var. geogr. typica festucetosum altissimae var. typica

It grows on sites with average ecological conditions of the subassociation festucetosum altissimae. These sites are gently steep to steep stony slopes overgrown abundantly with grass Festuca altissima. The plant combination has been rather impoverished, particularly on account of the differential species of the suballiance Saxifrago-Fagenion and the alliance Aremonio-Fagion as well as the class Querco-Fagetea.

The holotype is the same as for the subassociation.

Homogyno sylvestris-Fagetum var. geogr. typica festucetosum altissimae $\mathrm{f}$. Galium odoratum $\mathrm{f}$. nova hoc loco

It grows on more gentle slopes and plateaus at lower elevations below 1000 metres on medium deep to deep Chromic Cambisol with less pronounced surface ground rock cover. The differential species of the form are Galium odoratum, Hordelymus europaeus, Ranunculus lanuginosus and Sambucus nigra. With the species of the class QuercoFagetea: Clematis vitalba, Corylus avellana, Lonicera xylosteum, they indicate favourable soil and humid conditions and lower altitudes.

The holotypus of the form is relevé no. 35, Table no. 1.

Homogyno sylvestris-Fagetum var. geogr. typica festucetosum altissimae f. Luzula sylvatica f. nova hoc loco 
It thrives on higher elevations above sea level ranging from 1000 to 1300 metres. Very shady slopes and ridges with very pronounced surface stones predominate. The soil composition does not differ notably from the described soils of the subassociation, only that raw humus is more abundantly represented in the upper layers.

The differential species of the form is Luzula sylvatica, which grows very well on fresh soils, mostly poor in bases or on the calcareous bedrock where the raw humus eliminates to a certain extent the influence of the calcareous bedrock. Other differential species Rubus hirtus, Veronica urticifolia, Rosa pendulina show a moderately acidophilic character of the described form.

The holotypus of the form is relevé no. 46, Table no. 1.

Homogyno sylvestris-Fagetum var. geogr. typica luzuletosum sylvaticae subass. nova hoc loco

It thrives on higher elevations above sea level ranging from 1300 to 1450 metres and passes over directly to the association Adenostyles glabrae-Piceetum.

The subassociation grows on the remnants of the calcareous glacier loose rocks. Gently inclined slopes, plateaus and wide ditches predominate. There are skeletal Rendzina and shallow Chromic Cambisol, covered with well-rotted and partially raw humus on Dachstein limestones and triassic dolomites.The differential species of the subassociation are Calamagrostis villosa, Homogyne alpina, Huperzia selago, Luzula sylvatica, Lycopodium annotinum, Melampyrum sylvaticum and Vaccinium vitisidaea. Rosa pendulina, which has a high constancy and has also a partial differential character.

The species of the suballiance Saxifrago-Fagenion are very well represented regarding the number and cover of the species complying with the strong altimontane character of the community.

The species of the alliance Aremonio-Fagion are represented to a smaller extent. Particularly the species Hacquetia epipactis, Lamium orvala, Vicia oroboides, Primula vulgaris, Knautia drymeia subsp. drymeia, the species of the alliance AremonioFagion growing particularly in the submontane and montane belt and Omphalodes verna and Calamintha grandiflora, and the species with Dinaric distribution pattern, are completely missing. Special site conditions result also in a smaller cover of the species of beech forests. The facies of the species of Carex alba can be found on smaller surfaces.
The holotypus of the subassociation is relevé no. 50, Table no.1, holotypus hoc loco.

Homogyno sylvestris-Fagetum var. geogr. typica vaccinietosum myrtilli subass. nova hoc loco

It grows on the bottom of broad pre-Alpine valleys. It is particularly well developed in the valley of Logarska dolina, having a partial frost pocket character. Cold climatic conditions and abundant precipitation result in the predominance of raw humus and thus in the partially acidophilic character of the subassociation in the differential species combination, namely Vaccinium myrtillus, Rubus saxatilis, Bazzania trilobata. The partially acidophilic character of the subassociation is confirmed by the great cover value of the species Oxalis acetosella and the constant presence of the species Maianthemum bifolium, Hieracium sylvaticum and Phegopteris connectilis. Furthermore, the species Carex alba, which frequently grows luxuriantly on young soils over the deposited limestone gravel, is mentioned as the differential species. The sites of the subassociation are, in fact, periodically inundated by torrents. With regard to the lower altitudes of the subassociation (approx. 800 metres), it is clear that the species of the suballiance Saxifrago-Fagenion are less represented. The species Saxifraga rotundifolia was noted only once. Moreover, the species of the order Adenostyletalia are less represented.

The nomenclature type of the subassociation is relevé no. 59, Table no.1, holotypus hoc loco.

Numerical analysis and synsystematic spectrum

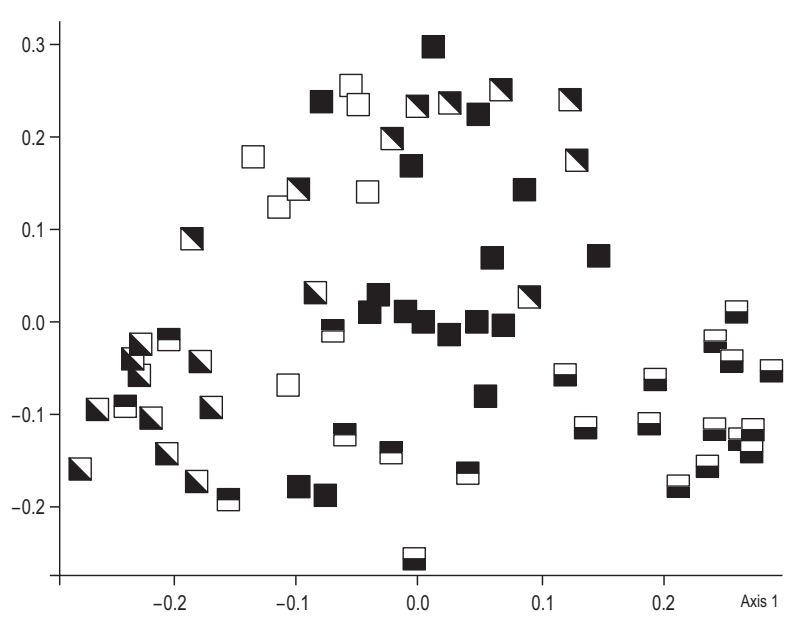

Figure 1: Numerical analysis of the Homogyno-Fagetum. Slika 1: Numerična analiza asociacije Homogyno-Fagetum.

$\square$ typicum, $\square$ mercurialetosum, $\nabla$ festucetosum altissimae, $\square$ calamagrostietosum variae, $\square$ luzuletosum sylvaticae, $\mathbf{\Delta}$ vaccinietosum myrtilli. 
The numerical analysis (Fig. 1) shows the gradient of the most acidophilic subassociation vaccinietosum over luzuletosum sylvaticae, calamagrostietosum variae, mercurialetosum, typicum to the most basiphilic subassociation festucetosum altissimae. Axis 2 reflects the thermicity. The most frigoriphilic subassociation festucetosum altissimae, vaccinietosum and luzuletosum sylvaticae over typicum to the most thermophilic calamagrostietosum and mercurialetosum.

The synsystematic spectrum (Fig. 2) shows that the classes Erico-Pinetea and Vaccinio-Piceetea are better repesented in the pre-Alpine and Alpine zone, whereas more species of the beech forest (Fagetalia) are revealed in the Dinaric Alps.

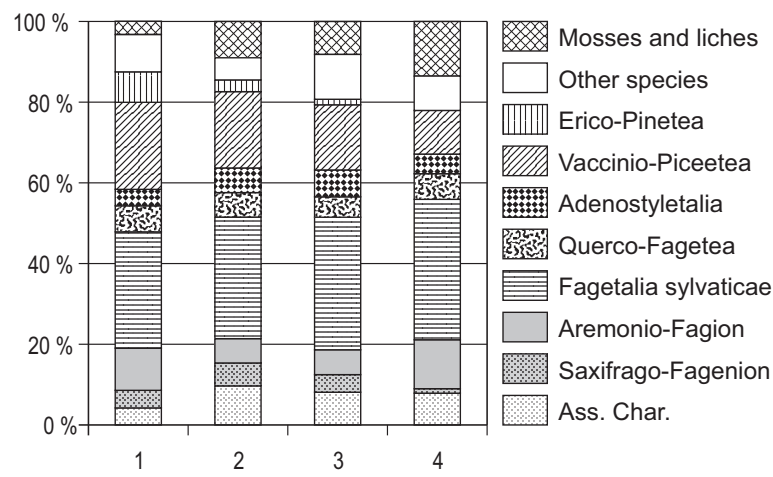

Figure 2: Synsystematic spectrum.

Slika 2: Sinsistematski spekter.

1 - Anemono trifoliae-Fagetum Tregubov 1962 (Marinček, Poldini \& Zupančič 1989); 2 - Homogyno sylvestris-Fagetum Marinček et al. 1993 (Marinček \& Čarni, Table 1) 3 - Omphalodo-Fagetum (Tregubov 1957) Marinček et al. 1993 var. geogr. Saxifraga cuneifolia (Surina 2001), 4 - OmphalodoFagetum (Tregubov 1957) Marinček et al. 1993 (Puncer 1980).

\section{DISCUSSION}

At the beginning of the discussion, it could already be confirmed that the study of the pre-Alpine fir and beech forests by Marinček \& Dakskobler (1988) has been neglected, or else the results of the studies of the pre-Alpin fir and beech forests were not published properly in comparison with the studies of the Dinaric forests of the association Omphalodo-Fagetum.

Since 1965, the basis for divulging the contents of the phytosociology of the pre-Alpine fir and beech forests was provided by a synthetic table of Robič (Košir et al. 1968), in which was presented the phytosociological composition of the pre-Al- pine fir and beech forests on the calcareous (Abieti-Fagetum praealpino-dinaricum) as well as on the noncalcareous bedrock (Abieti-Fagetum praealpinodinaricum luzuletosum albidae).

This was used for the first time for comparisons with the pre-Alpine fir and beech forests in the above mentioned discussion by Marinček and Dakskobler. Taking into consideration the opinion of Robič, the authors mentioned for the pre-Alpine fir and beech forests as character species and differential species (Abieti-Fagetum praealpinum $=$ Homogyno sylvestris-Fagetum): Adenostyles glabra, Polygonatum verticillatum, Ranunculus platanifolius, Veronica urticifolia, Anemone trifolia and Festuca altissima. The revision of the nomenclature of the Illyrian beech forests of the alliance Aremonio-Fagion (Marinček et al. 1993) introduced the binomial designation of forest communities on the floristic basis.

A constant, but more or less abundant presence of fir in a tree layer results in certain ecological contents of these forests. Fir and beech forests thrive in special ecological conditions, as mentioned in the introduction. Its constant mixture differentiates the association Homogyno sylvestrisFagetum from more or less pure beech forests bordering the described association, either from the Alpine beech forests Anemono-Fagetum or from altimontane beech forests of the pre-Alpine region of the Illyrian floral province Ranunuculo platanifolii-Fagetum var. geogr. Hepatica nobilis or the subAlpine beech forests of type Polysticho lonchitis-Fagetum var. geogr. Salix waldsteiniana.

With regard to the relatively weak character species of the association, the differential species are rather more significant. Marinček \& Dakskobler (1988) stated Adenostyles glabra, Polygonatum verticillatum, Ranunculus platanifolius, Veronica urticifolia, Anemone trifolia as differential species of the pre-Alpine fir and beech forests. The association Homogyno sylvestris-Fagetum has only recently been attached to the suballiance Saxifrago-Fagenion (Marinček et al. 1993). The differential species of the suballiance Adenostyles glabra, Polygonatum verticillatum and Ranunculus platanifolius, however, indicate very well the altimontane site conditions of stands of the association Homogyno sylvestrisFagetum, although they cannot function as their differential species at the same time.

The differential species of the association is a whole series of moderately acidophilic to acidophilic species such as Veronica urticifolia, Valeriana tripteris, Vaccinium myrtillus, Rubus saxatilis, Hieracium sylvaticum, Vaccinium vitis-idaea and Larix 
decidua. The species listed indicate a more acidic form of humus as the consequence of a colder $\mathrm{Al}$ pine climate and higher elevations above sea level (according to Marinček \& Dakskobler 1988, see also Marinček 1983).

As indicated in the introduction, the association Homogyno sylvestris-Fagetum belongs to the alliance of Illyrian beech forests Aremonio-Fagion. The floristic composition, ecological and synecological conditions of the associations Lamiastro flavidi-(Abieti)-Fagetum Zukrigl 1987 (=Lamiastro flavidi-Fagetum) and Savensi-Fagetum var. Abies alba Košir 1962 (=Cardamino savensi-Fagetum) and the comparison with the pre-Alpine fir and beech forests on the calcareous bedrock have already been dealt with by Marinček \& Dakskobler (1988). This discussion will be limited to the ecological and floristic comparison with the Alpine beech forests Anemono-trifoliae-Fagetum Tregubov 1962, and with the Dinaric fir and beech forests Omphalodo-Fagetum (Tregubov 1957 corr. Puncer 1980) Marinček et al. 1993.

The ecological and floristic comparison between Dinaric (Omphalodo-Fagetum) and pre-Alpine fir and beech forests (Homogyno sylvestris-Fagetum) arouses great interest. The Dinaric fir and beech forests are a prototype of the Illyrian fir and beech forests. Favourable edaphic conditions result from the predominant limestone bedrock, on which the karstic relief is completely developed. It produces constantly high air humidity and predominantly well developed Chromic Cambisol as a result of abundant precipitation. In this way optimal conditions for the growth of fir and beech forests within the European region are provided. Favourable site edaphic conditions, particularly the well developed Chromic Cambisol in comparison with the pre-Alpine fir and beech forests are indicated by mezophilic and neutrophilic species such as Galium odoratum, Carex sylvatica, Myosotis sylvatica, Solanum dulcamara, Chrysosplenium alternifolium, Urtica dioica which do not appear, or appear only seldom in the association Homogyno sylvestris-Fagetum. In particular, they differ among themselves floristically with regard to the presence and cover the size of character species and differential species of the alliance Aremonio-Fagion. The Dinaric fir and beech forests grow in the centre of the Illyrian floral province, and the species as Omphalodes verna, Calamintha grandiflora, Primula vulgaris,
Hacquetia epipactis, Euphorbia carniolica and Rhamnus fallax are well represented. Hence, they appear more or less as accidental species in stands of the association Homogyno sylvestris-Fagetum. Moreover, they reach a high constancy and coverage value in the association Omphalodo-Fagetum and give a characteristic feature to Dinaric fir and beech forests. Additionally, species like Dentaria trifolia, Scopolia carniolia, Dentaria polyphylla and Daphne laureola are diagnostically very significant for the fir and beech forests. They do not appear at all in the syntaxon Homogyno sylvestris-Fagetum var. geogr. typica.

The pre-Alpine fir and beech forests grow in more rough ecological conditions compared to the Dinaric forests. The climate of the pre-Alpine and Alpine region is colder, edaphic conditions are more initial because of the predominant dolomite bedrock. Furthermore, higher altitudes cause the formation of well-rotted and raw humus.

The bordering location of the site of the association Homogyno sylvestris-Fagetum at the edge of the Illyrian floral province is also of great importance. Particularly, ecologically more demanding species of beech forests and differential species of the alliance Aremonio-Fagion have a lower vitality and are less frequently encountered. On the other hand, there is a whole series of acidophilic elements in the association Homogyno sylvestris-Fagetum like Veronica urticifolia, Valeriana tripteris, Vaccinium myrtillus, Rubus saxatilis, Hieracium sylvaticum, Vaccinium vitis-idaea and Larix decidua which clearly differentiate the pre-Alpine fir and beech forests from the Dinaric forests. Mention should be made of the species Larix decidua which appears mainly at the highest altitudes. However, its presence indicates the partially Alpine character of the association.

Differential species of the association Anemono trifoliae-Fagetum are also a group of species of the order Erico-Pinetalia: Pinus sylvestris, Buphthalmum salicifolium, Erica carnea, Polygala chamaebuxus and some other species. They reach an optimal development in the Alpine beech forests, particularly at lower altitudes (Anemono trifoliae-Fagetum var. geogr. Helleborus niger cephalantheretosum) and in more extreme sites in relation to the land configuration. However, their appearance in the distribution area of the association indicates their specific syngeneses and relationship with the association Orno-Pinetum nigrae. 


\section{REFERENCES}

Barkman, J. J., Moravec, J. \& Rauschert S. 1986: Code of Phytosociological Nomenclature. Vegetatio 67: 145-195.

Borhidi, A. 1963: Die Zönologie des Verbandes Fagion illyricum Allgemenier Teil. Acta Bot. Acad. Sc. Hung. 9: 259-298.

Braun-Blanquet, J. 1964: Pflanzensoziologie. Grundzüge der Vegetationskunde. 3. Aufl. Springer, Wien, 865 pp.

Dakskobler, I., Urbančič, M. \& Wraber, A. 2000: Gozd bukve in jelke z dlakavim slečem (Omphalodo-Fagetum rhododendrosum hirsuti) v Trnovskem gozdu (Zahodna Slovenija). Zbornik gozdarstva in lesarstva 62: 5-52.

Dakskobler, I. 2002: Jelovo-bukovi gozdovi na Bovškem (Julijske Alpe, severozahodna Slovenija). Razprave IV. razreda SAZU 43(2): 109-155.

Dakskobler, I. 2002a: Jelovo-bukovi gozdovi v dolini Kneže, Zadlaščice in Tolminke (Južne Julijske Alpe, zahodna Slovenija). Razprave IV. razreda SAZU 43(3): 111-165.

Dakskobler, I. 2002b: Jelovo-bukovi gozdovi v zgornji Baški dolini (Julijske Alpe, zahodna Slovenija. Hacquetia 1(1): 35-88.

Dakskobler, I. 2004: Jelovo-bukovi gozdovi v dolini Loške Koritnice v Julijskih Alpah (severozahodna Slovenija). Gozdarski vestnik 62(7/8): 299-315.

Ehrendorfer, F. 1973: (ed.): Liste der Gefässpflanzen Mitteleuropas. 2. Aufl., Gustav Fischer Verl., Stuttgart.

Franjić, J., Škvorc, Ž. \& Čarni, A. 2001: Numerička analiza fitocenoloških snimaka u bukovo-jelovim šumama (Abieti-Fagetum s. lat.) u Hrvatskoj. Šumarski list 125(1-2): 19-26.

Frey W., Frahm, J.-P., Fischer, E. \& Lobin, W. 1995: Die Moos- und Farnpflanzen Europas. 6. Aufl., Gustav Fischer Verlag, Stuttgart.

Horvat, I. 1938: Biljnosociološka istraživanja šuma u Hrvatskoj. Glasnik za šumske pokuse 6: 127279.

Horvat, I., Glavač, V. \& Ellenberg, H. 1974: Vegetation Südosteuropas. Gustav Fischer Verlag, Stuttgart, $767 \mathrm{pp}$.

Kordiš, F. 1993: Dinarski jelovo bukovi gozdovi v Sloveniji. Strokov. znan. dela 112, 139 pp.

Košir, Ž., Zorn, M. \& Robič, D. 1968: Gozdne združbe gospodarske enote Jelendol. Biro za gozdarsko načrtovanje, Ljubljana (Elaborat, legenda vegetacijskih kart in fitocenološke preglednice).
Maarel, van der, E. 1979: Transformation of coverabundance values in phytosociology and its effect on community similarity. Vegetatio 39: 97-114.

Marinček, L. 1973a: Gozdna vegetacija Loškega pogorja. Loški razgledi, 20: 208-226.

Marinček, L. 1973b: Gozdne združbe Zgornje Selške doline. Biro za gozdarsko načrtovanje, Ljubljana.

Marinček, L.1978: Vegetacijska in rastiščna analiza za območje gozdnogospodarske enote Jelendol. GG Kranj, Kranj.

Marinček, L. 1983: Visokogorsko acidofilno bukovje v Sloveniji. Akademija nauka i umjetnosti BiH. Radovi 72(21): 405-415.

Marinček, L. 1987: Bukovi gozdovi na Slovenskem. Delavska enotnost, Ljubljana, 153 pp.

Marinček, L. 1995: Contribution to the demarcation and phytogeographic division of the Illyrian floral province, based on the vegetation and flora. Gortania 16: 99-124.

Marinček, L. \& Dakskobler, I. 1988: Acidofilni jelovo-bukovi gozdovi predalskega sveta Slovenije Luzulo-Abieti-Fagetum praealpinum var. geogr. nova. Razprave 4. razr. SAZU 29: 29-67.

Marinček, L., Poldini, L. \& Zupančič, M. 1989: Beitrag zur Kenntnis der Gesellschaft Anemono-Fagetum. Razprave 4. razr. SAZU 30(1): 2-64.

Marinček, L., Mucina, L., Zupančič, M., Poldini, L., Dakskobler, I. \& Accetto, M. 1993 (1992): Nomenklatorische Revision der illyrischen Buchenwälder. Studia Geobotanica 12: 121-135.

Martinčič, A. 2003: Seznam listnatih mahov (Bryopsida) Slovenije. Hacquetia 2(1): 91-166.

Mekinda-Majaron, T. 1995: Klimatografija Slovenije: temperature zraka: obdobje 1961-1990. Hidrometeorološki zavod Slovenije, Ljubljana.

Ovsenik-Jeglič, T. 2000: Klimatografija Slovenije. Število dni s snežno odejo: 1961-1999. Ministrstvo za okolje in prostor, Ljubljana.

Podani, J. 2001: SYN-TAX 2000. Computer program for data analysis in ecology and systematics, Scientia publishing, Budapest.

Praprotnik, N. 1987: Ilirski florni elementi v Sloveniji. Doctoral thesis. Biotehniška fakulteta. Univerza v Ljubljani, Ljubljana, 243 pp.

Puncer, I. 1979: Ekološke in floristične značilnosti združbe Abieti-Fagetum na Trnovskem gozdu. Drugi kongres ekologa Jugoslavije 1, Zadar-Plitvice, p. 925-938.

Puncer, I. 1980: Dinarski jelovo-bukovi gozdovi na Kočevskem. Razprave 4. razr. SAZU, 22(6): 407-561. 
Puncer, I., Wojterski, T. \& Zupančič, M. 1974: Der Urwald Kočevski Rog in Slowenien (Jugoslawien). Fragmenta floristica et geobotanica 20(1): 41-87.

Seidl, F.1907-1908: Kamniške ali Savinjske Alpe, njih zgradba in njih lice. Matica Slovenska 1/2: 1-255, Ljubljana.

Surina, B. 2001: Fitocenološke raziskave jelovo-bukovega gozda (Omphalodo-Fagetum s. lat.) v zahodnem delu ilirske florne province. Master's thesis. Biotehniška fakulteta, Univerza v Ljubljani, Ljubljana, 99 pp.

Surina, B. 2002: Phytogeographical differentiation in the Dinaric fir-beech forest (OmphalodoFagetum) of the western part of the Illyrian floral province. Acta Botanica Croatica 61: $145-178$.

Tregubov, V. \& Čokl, M. 1957 (ed.): Prebiralni gozdovi na Snežniku Vegetacijska in gozdnogospodarska monografija. Strokovna in znanstvena dela IGLGS 4, 165 pp.
Tregubov, V. 1962: Naravni sestoji macesna in gospodarjenje z njimi. Zborn. Inst. gozd. les. gospod. Slovenije 3: 29-143.

Weber, H.E., Moravec, J. \& Theurillat, J.P. 2000: International Code of Phytosociological Nomenclature. $3^{\text {rd }}$ edition. Journal of Vegetation Science 11: 739-768.

Wirth, V. 1995: Flechtenflora. Bestimmung und ökologische Kennzeichnung der Flechten Südwestdeutschlands und angrenzender Gebiete. 2. Aufl. Eugen Ulmer Verlag, Stuttgart.

Wraber, M. 1960: Fitocenološka razčlenitev gozdne vegetacije v Sloveniji. Zbornik ob 150-letnici Botaničnega vrta v Ljubljani, Univerza $\mathrm{v}$ Ljubljani, Ljubljana, p. 49-96.

Zukrigl, K. 1989: Die montanen Buchenwälder der Nordabdachung der Karawanken und Karnischen Alpen. Naturschutz in Kärnten 9: 1-116.

Zupančič, B. 1995. Klimatografija Slovenije. Količina padavin: obdobje 1961-1990. Hidrometeorološki zavod Republike Slovenije, Ljubljana. 
Table 1: Illyrian pre-alpine fir and beech forest - the association Homogyno sylvestris-Fagetum Marinček et al. 1993

Tabela1: Ilirski predalpski jelovo-bukovi gozdovi - asociacija Homogyno sylvestris-Fagetum Marinček et al. 1993

\begin{tabular}{|c|c|c|c|c|c|c|c|c|c|c|c|c|c|c|c|c|c|c|c|c|c|c|c|c|c|c|c|c|c|c|c|c|c|}
\hline \multicolumn{2}{|l|}{ Relevé no. } & 1 & 2 & 3 & 4 & 5 & 6 & 7 & 8 & 9 & 10 & 11 & 12 & 13 & 14 & 15 & 16 & 17 & 18 & 19 & 20 & 21 & 22 & 23 & 24 & 25 & 26 & 27 & 28 & 29 & 30 & 31 & 32 \\
\hline \multicolumn{2}{|l|}{ Alitude (in $10 \mathrm{~m}$ ) } & 97 & 101 & 102 & 78 & 98 & 96 & 107 & 76 & 1411 & 145 & 105 & 106 & 119 & 105 & 70 & 110 & 1011 & 1251 & 1011 & 125 & 1201 & 130 & 108 & 96 & 100 & 103 & 107 & 73 & 75 & 106 & 1001 & 129 \\
\hline \multicolumn{2}{|l|}{ Aspect } & W & $\mathrm{NE}$ & NW & $\mathrm{N}$ & $\mathrm{N}$ & S & $\mathrm{NE}$ & EN & $\mathrm{S}$ & $\mathrm{W}$ & E & NE 1 & NW & $\mathrm{N}$ & $\mathrm{pl}$ & $\mathrm{N}$ & $\mathrm{NE}$ & $\mathrm{S}$ & $\mathrm{S}$ & W & $\mathrm{W}$ & $\mathrm{S}$ & SW & SE & NW & $\mathrm{NE}$ & $\mathrm{N}$ & SE & $\mathrm{N}$ & NW & $\mathrm{N}$ & $\mathrm{S}$ \\
\hline \multicolumn{2}{|l|}{ Slope ( in degrees) } & 15 & 35 & 30 & 35 & 30 & 20 & 25 & 10 & 15 & 20 & 5 & 30 & 15 & 20 & & 10 & 15 & 35 & 15 & 30 & 40 & 25 & 30 & 30 & 30 & 30 & 35 & 40 & 35 & 35 & 45 & 20 \\
\hline \multicolumn{2}{|l|}{ Rock coverage (in \%) } & 15 & & 10 & 1 & 20 & 5 & & 60 & 30 & 20 & 40 & 20 & & 15 & 1 & 10 & 40 & 70 & 30 & & 5 & 40 & 5 & & 10 & & 30 & 10 & & 40 & 35 & 20 \\
\hline \multicolumn{2}{|l|}{ Surface (in $\mathrm{m}^{2}$ ) } & 400 & 400 & 400 & 400 & 400 & 400 & 400 & 400 & 4004 & 400 & 400 & 400 & 400 & 400 & 400 & 400 & 4004 & 4004 & 4004 & 400 & 4004 & 400 & 400 & 400 & 400 & 400 & 400 & 400 & 400 & 400 & 4004 & 400 \\
\hline \multicolumn{34}{|l|}{ Coverage (in \%) } \\
\hline- tree layer & A & 90 & 95 & 90 & 90 & 80 & 90 & 80 & 80 & 80 & 90 & 90 & 90 & 80 & 95 & 90 & 90 & 90 & 70 & 90 & 85 & 90 & 80 & 80 & 90 & 95 & 90 & 90 & 90 & 95 & 95 & 80 & 80 \\
\hline - shrub layer & B & 30 & 2 & 2 & 15 & 30 & 30 & 30 & 70 & 2 & 10 & 5 & 5 & 20 & 5 & 20 & 5 & 10 & 102 & 20 & 5 & 15 & 10 & 30 & 5 & 5 & 5 & 2 & 25 & 20 & 10 & 20 & 5 \\
\hline - herb layer & $\mathrm{C}$ & 80 & 30 & 30 & 30 & 50 & 50 & 40 & 60 & 30 & 90 & 70 & 40 & 40 & 20 & 70 & 30 & 50 & 50 & 60 & 70 & 60 & 80 & 60 & 40 & 50 & 40 & 40 & 70 & 80 & 50 & 50 & 80 \\
\hline - moos layer & D & 10 & 1 & 2 & 5 & 5 & 5 & & 30 & 2 & 5 & 40 & 20 & & 10 & & 5 & 20 & 10 & 10 & & 5 & & 5 & & & & 5 & 10 & & 20 & 20 & 20 \\
\hline Subasociations & & & & & & & & & picun & & & & & & & & & & calan & Imag & rost & $\begin{array}{l}\text { tietos } \\
\text { e }\end{array}$ & & & & & & ercu & riale & etosu & & & \\
\hline Lower units & & 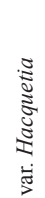 & & & & & & & & & & & & & & 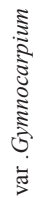 & 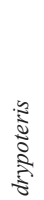 & & & & & & & & & 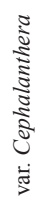 & & & & 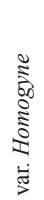 & 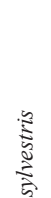 & & \\
\hline
\end{tabular}

Char. species of ass.

Homogyne sylvestris

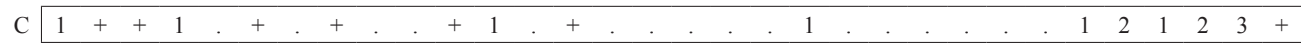

Diff. species of subass.

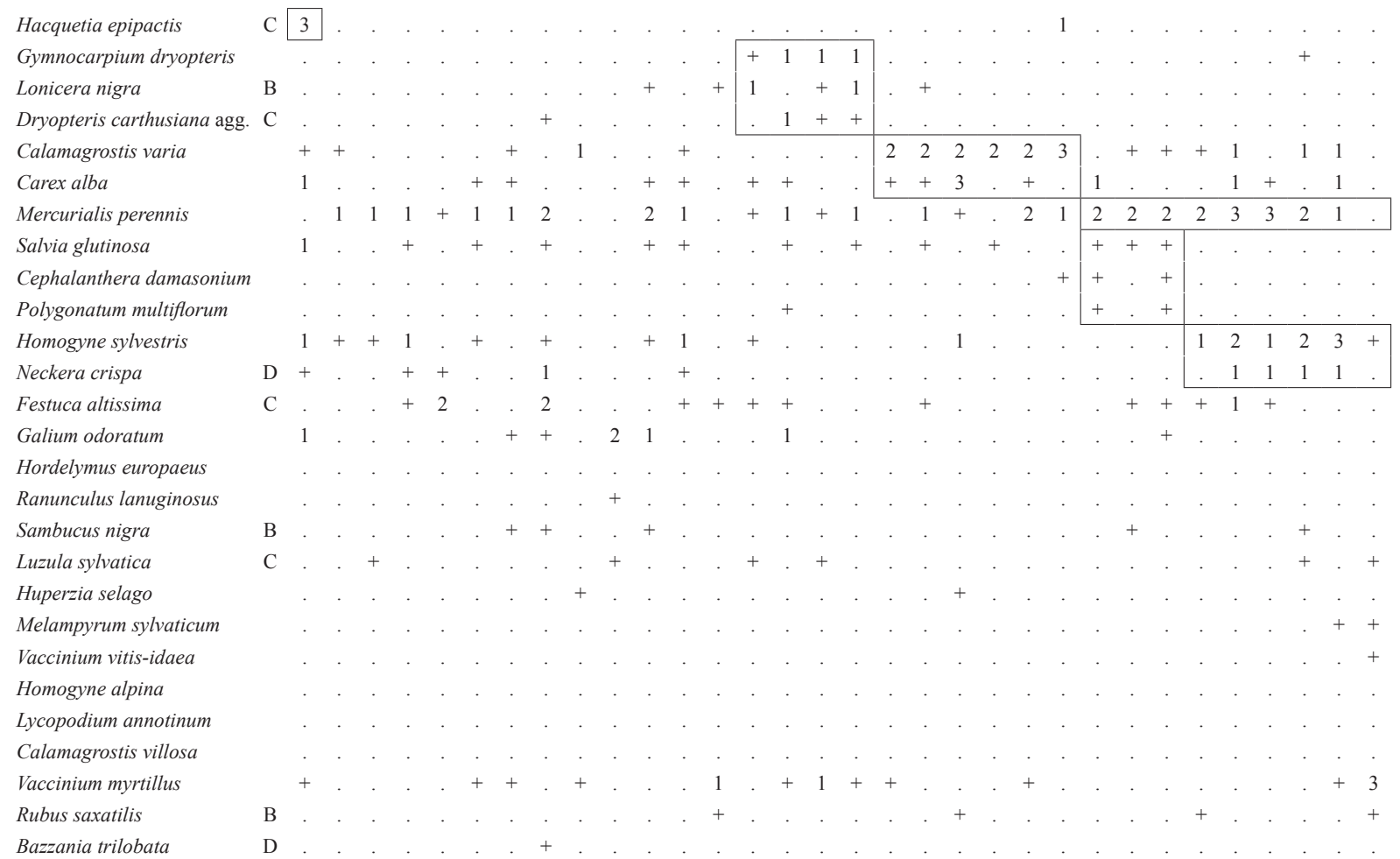

Saxifrago-Fagenion

Polygonatum verticillatum Adenostyles glabra 
\begin{tabular}{lllllllllllllllllllllllllllllllll}
33 & 34 & 35 & 36 & 37 & 38 & 39 & 40 & 41 & 42 & 43 & 44 & 45 & 46 & 47 & 48 & 49 & 50 & 51 & 52 & 53 & 54 & 55 & 56 & 57 & 58 & 59 & 60 & 61 & 62 & 63 & 64 & 65 \\
\hline & 102 & 98 & 83 & 93 & 10 & 1 & 123 & 28 & 07 & 14 & 11 & 26 & 20 & & &
\end{tabular}

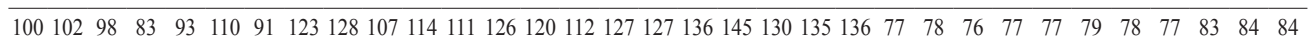

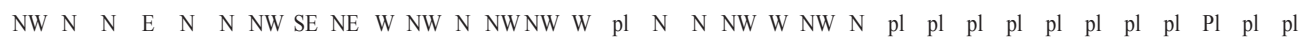
$\begin{array}{lllllllllllllllllllllllllllllllll}20 & 2 & 20 & 15 & 35 & 25 & 30 & 35 & 25 & 25 & 25 & 20 & 20 & 15 & 25 & 10 & 30 & 20 & 10 & 10 & 30 & 0 & 2 & 0 & 0 & 0 & 2 & 2 & 0 & 0 & 0 & 0\end{array}$ $\begin{array}{llllllllllllllllllllllllllllllll}30 & 10 & 5 & 5 & 20 & 30 & 35 & 20 & 30 & 5 & 30 & 30 & 30 & 40 & 25 & 60 & 30 & 30 & 20 & 20 & 30 & 0 & 0 & 0 & 0 & 0 & 0 & 0 & 0 & 0 & 10 & 20\end{array}$ 400400400400400400400400400400400400400400400400400400400400400400400400400400400400400400400400400

$\begin{array}{lllllllllllllllllllllllllllllllll}90 & 90 & 90 & 80 & 70 & 80 & 80 & 90 & 80 & 90 & 95 & 90 & 100 & 70 & 95 & 70 & 70 & 70 & 80 & 80 & 80 & 70 & 90 & 80 & 100 & 100 & 100 & 90 & 80 & 90 & 80 & 90 & 100\end{array}$ $\begin{array}{lllllllllllllllllllllllllllllllll}20 & 15 & 10 & 15 & 15 & 10 & 20 & 2 & 5 & 10 & 10 & 10 & 20 & 60 & 10 & 30 & 20 & 2 & 30 & 2 & 2 & 2 & 20 & 30 & 10 & 50 & 30 & 20 & 30 & 5 & 30 & 10 & 10\end{array}$ $\begin{array}{llllllllllllllllllllllllllllllllll}80 & 90 & 80 & 90 & 60 & 80 & 90 & 70 & 70 & 90 & 70 & 70 & 70 & 70 & 70 & 70 & 90 & 80 & 80 & 80 & 70 & 80 & 80 & 70 & 40 & 80 & 70 & 90 & 40 & 80 & 70 & 70 & 70\end{array}$

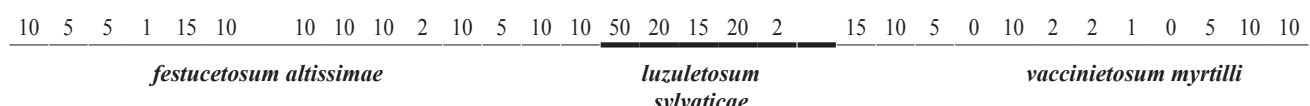
sylvaticae
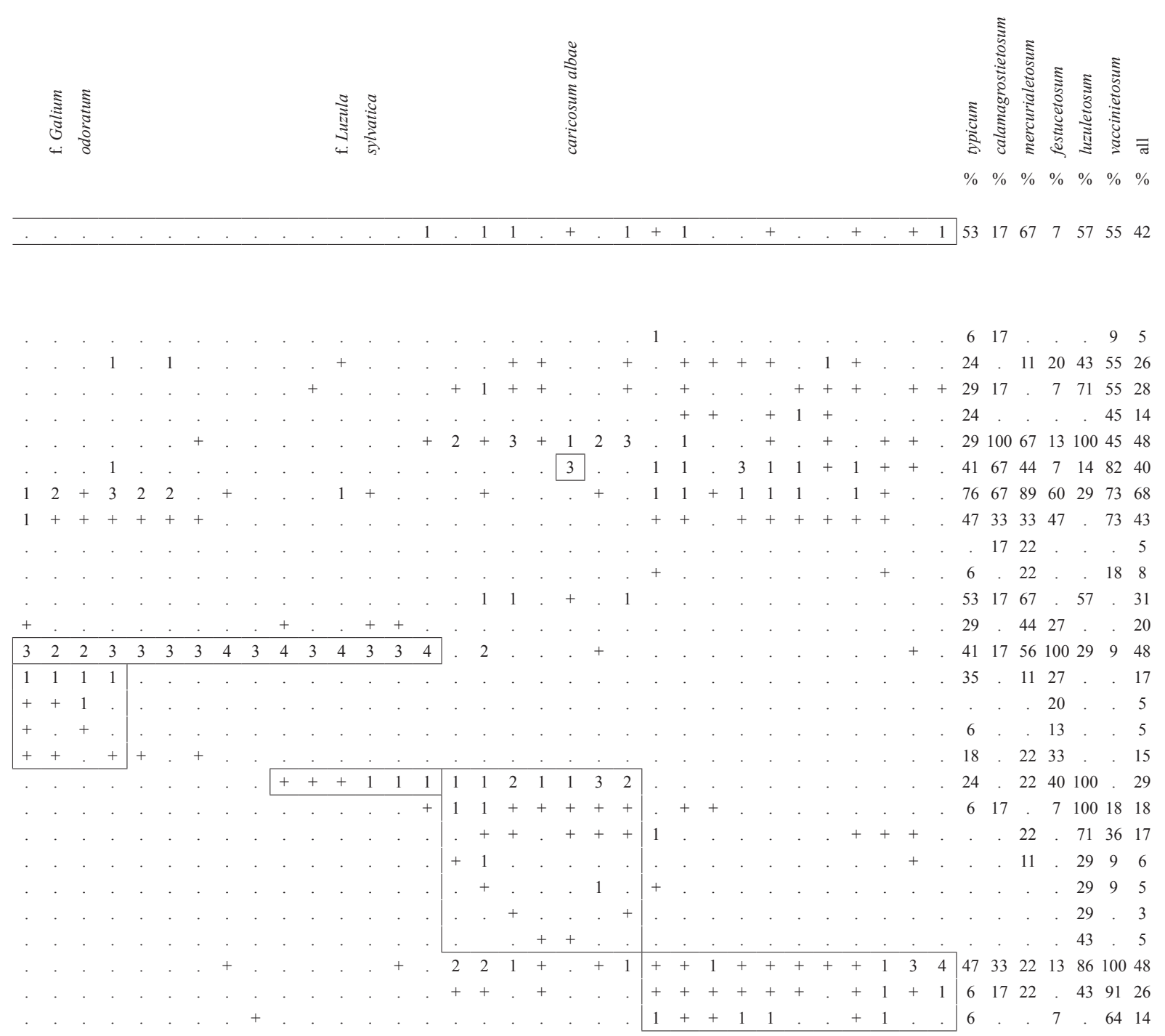

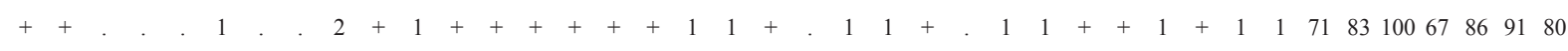

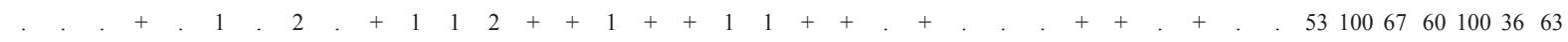


Relevé no.

$\begin{array}{llllllllllllllllllllllllllllllll}1 & 2 & 3 & 4 & 5 & 6 & 7 & 8 & 9 & 10 & 11 & 12 & 13 & 14 & 15 & 16 & 17 & 18 & 19 & 20 & 21 & 22 & 23 & 24 & 25 & 26 & 27 & 28 & 29 & 30 & 31 & 32\end{array}$

Ranunculus platanifolius

Clematis alpina

Saxifraga rotundifolia

B

Polystichum lonchitis

Adenostyles alliariae

\section{Aremonio - Fagion}

Cardamine trifolia

Dentaria enneaphyllos

Cyclamen purpurascens

Aposeris foetida

Helleborus niger

Aremonia agrimonoides

Lamium orvala

Fagetalia sylvaticae

Fagus sylvatica

Fagus sylvatica

Fagus sylvatica

Lamiastrum montanum et flavidum

Prenanthes purpurea

Daphne mezereum

Mycelis muralis

Acer pseudoplatanus

Acer pseudoplatanus

Acer pseudoplatanus

Euphorbia amygdaloides

Paris quadrifolia

Polystichum aculeatum

Viola reichenbachiana

Actaea spicata

Phyteuma sp.

Lonicera alpigena

Petasites albus

Sanicula europaea

Fraxinus excelsior

Melica nutans

Epilobium montanum

Lilium martagon

Symphytum tuberosum

Scrophularia nodosa

Pulmonaria officinalis

Acer platanoides

Brachypodium sylvaticum

Carex sylvatica

Dentaria bulbifera

Neottia nidus-avis

Geranium robertianum

Adoxa moschatellina

Aruncus dioicus

Epipactis helleborine

Fragaria moschata

Querco - Fagetea

Anemone nemorosa

Carex digitata

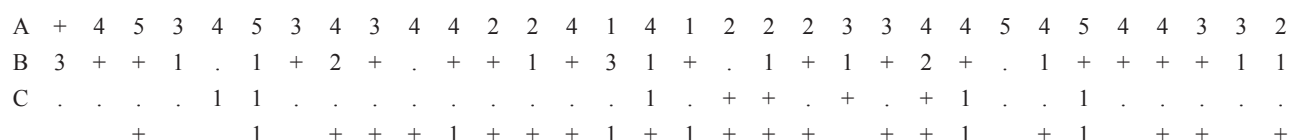

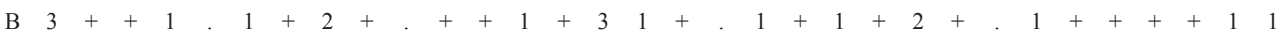

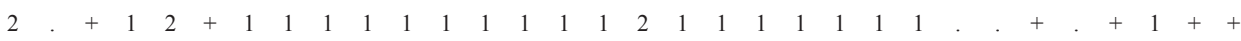

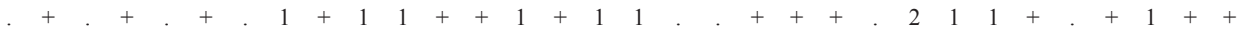

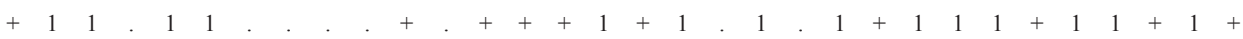

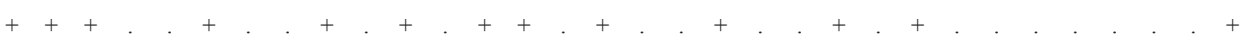

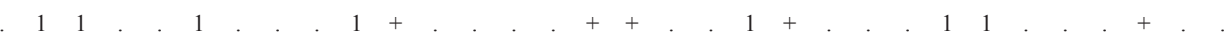


$\begin{array}{lllllllllllllllllllllllllllllllll}33 & 34 & 35 & 36 & 37 & 38 & 39 & 40 & 41 & 42 & 43 & 44 & 45 & 46 & 47 & 48 & 49 & 50 & 51 & 52 & 53 & 54 & 55 & 56 & 57 & 58 & 59 & 60 & 61 & 62 & 63 & 64 & 65\end{array}$

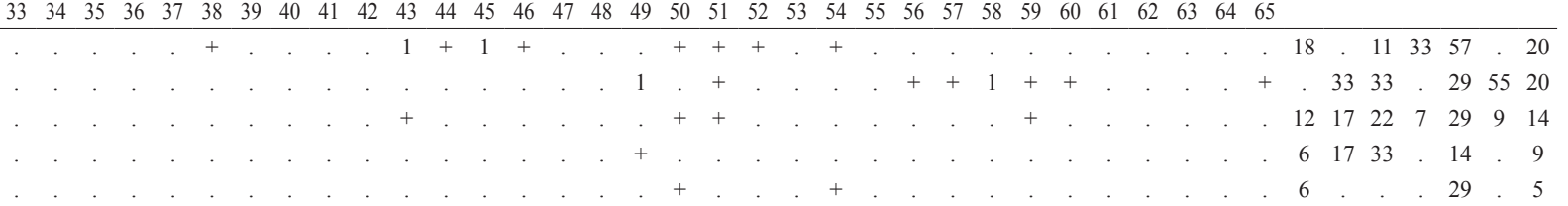

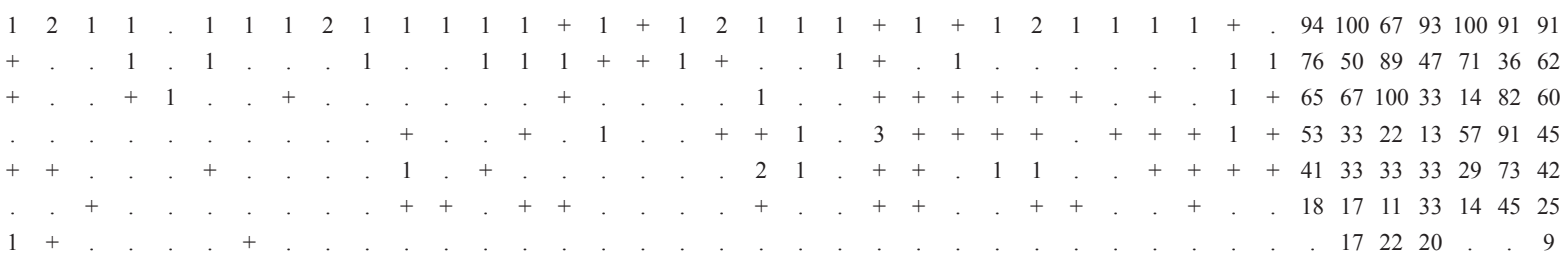

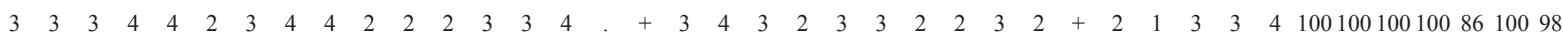

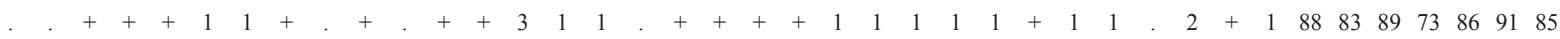

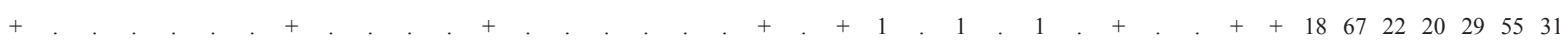

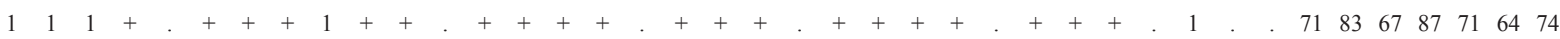

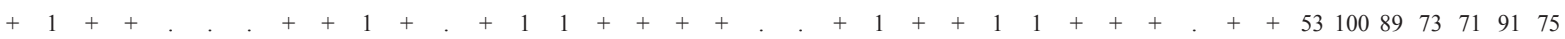

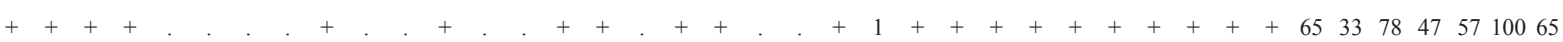

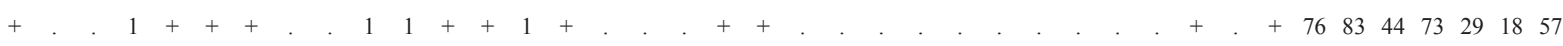

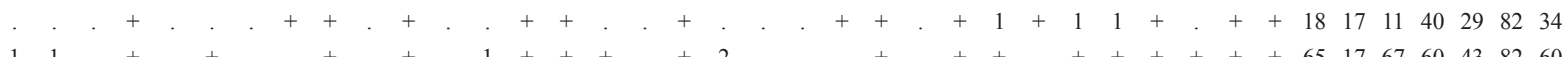

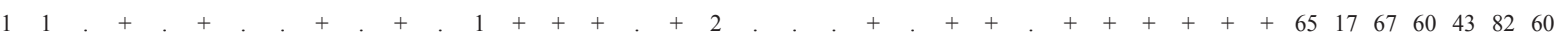

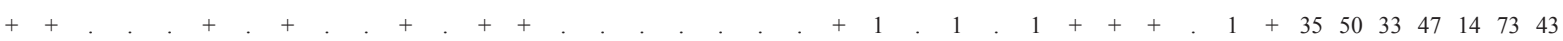

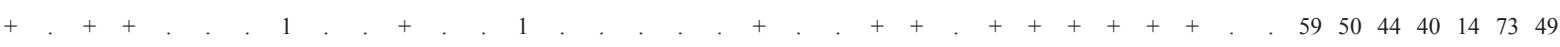

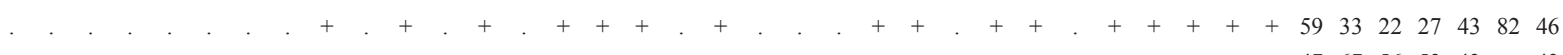

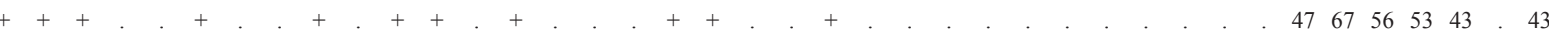

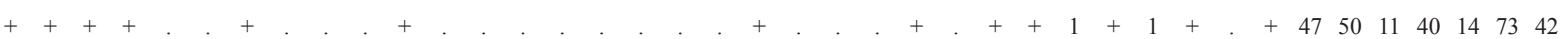

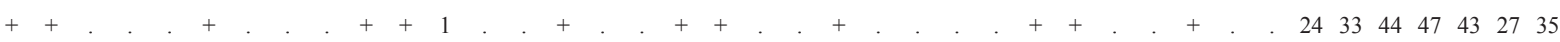

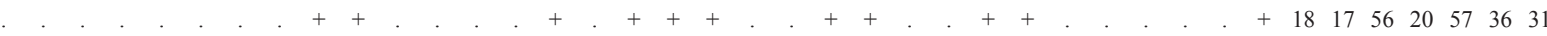

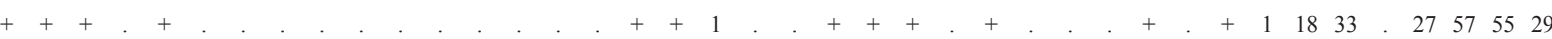

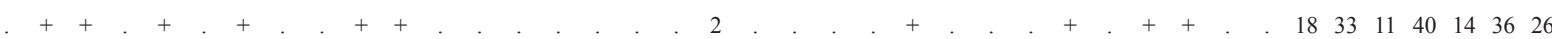

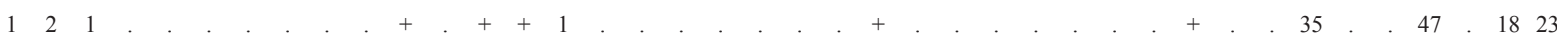

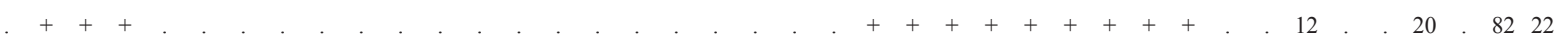
$\begin{array}{lll}14 & 27 & 17\end{array}$ $\begin{array}{lllllll}6 & 17 & 11 & 33 & 14 & . & 14\end{array}$ $18.22 . \quad 3614$ $\begin{array}{r}61711.292712 \\ \hline\end{array}$ $18 . \quad 27 . \quad 11$ $\begin{array}{lllllll}6 & 17 & 11 & 13 & . & 8\end{array}$ $6.1120 . \quad 8$ $\begin{array}{lllllll}6 & 17 & . & 7 & 18 & 8\end{array}$ $6 . \quad 20.98$ $\begin{array}{llllll}6 & . & 20 & 9 & 8\end{array}$ $24 . \quad . \quad 6$ $12 . \quad 13.6$ $\begin{array}{lllll}17 & 11 \quad 7 \quad 5\end{array}$ $\begin{array}{llll}7 & 14 & 9 & 5\end{array}$ 20 . 5 7.185 


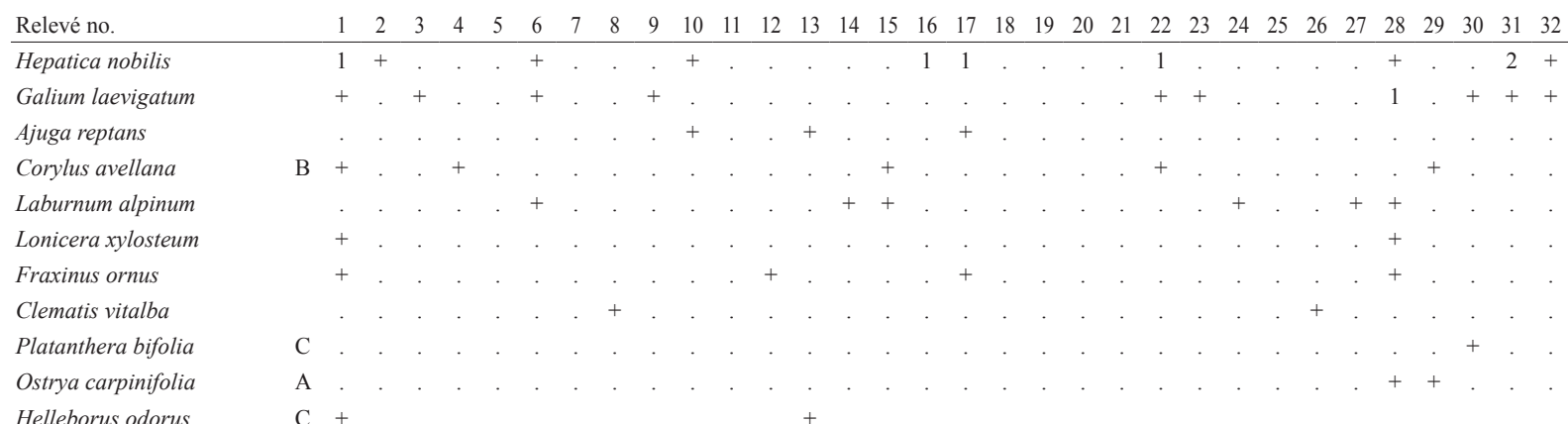

Adenostyletalia

Dryopteris filix-mas

Senecio ovatus

Athyrium filix-femina

Veratrum album

Ribes alpinum

Doronicum austriacum

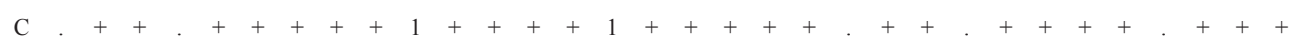

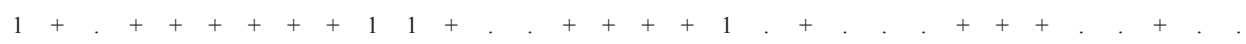
$\mathrm{B}$

C

\section{Vaccinio - Piceetea}

Abies alba

Abies alba

Abies alba

Picea abies

Picea abies

Picea abies

Oxalis acetosella

Veronica urticifolia

Gentiana asclepiadea

Valeriana tripteris

Hieracium sylvaticum

Maianthemum bifolium

Rosa pendulina

Solidago virgaurea

Luzula luzuloides

Thelypteris phegopteris

Dryopteris assimilis

Saxifraga cuneifolia

Larix decidua

Calamagrostis arundinacea $\mathrm{C}$

Luzula luzulina

Luzula pilosa

\section{Other species}

Sorbus aucuparia

Rubus idaeus

Fragaria vesca

Asplenium viride

Sorbus aria

Digitalis grandiflora

Veronica officinalis

Cirsium erisithales

Aquilegia vulgaris agg.

Rubus hirtus

Hypericum montanum

Eupatorium cannabinum

B

\section{C}

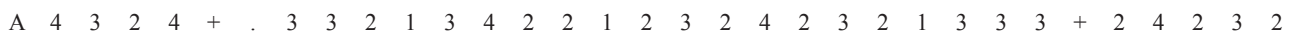

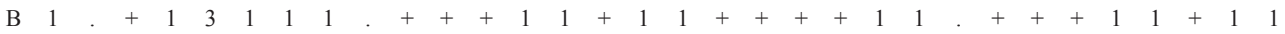

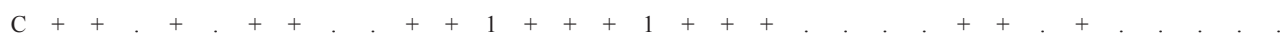

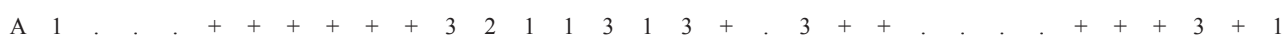

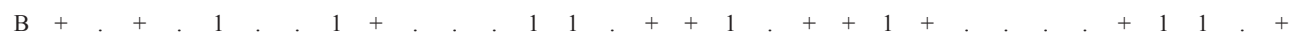

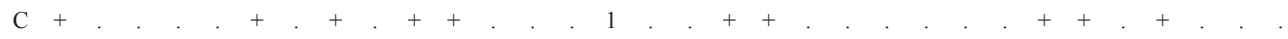

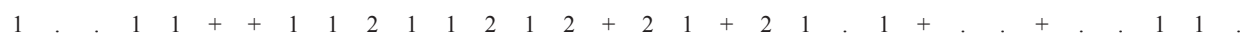

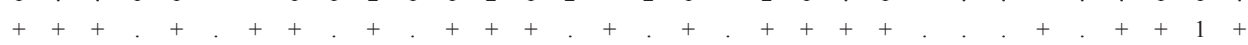

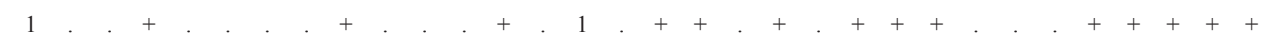

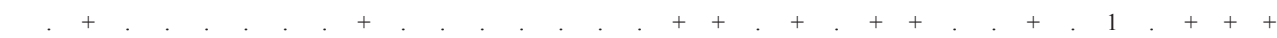

B

$\mathrm{A}$

$.+{ }^{+}+{ }^{+} \cdot{ }^{+} \cdot$ 

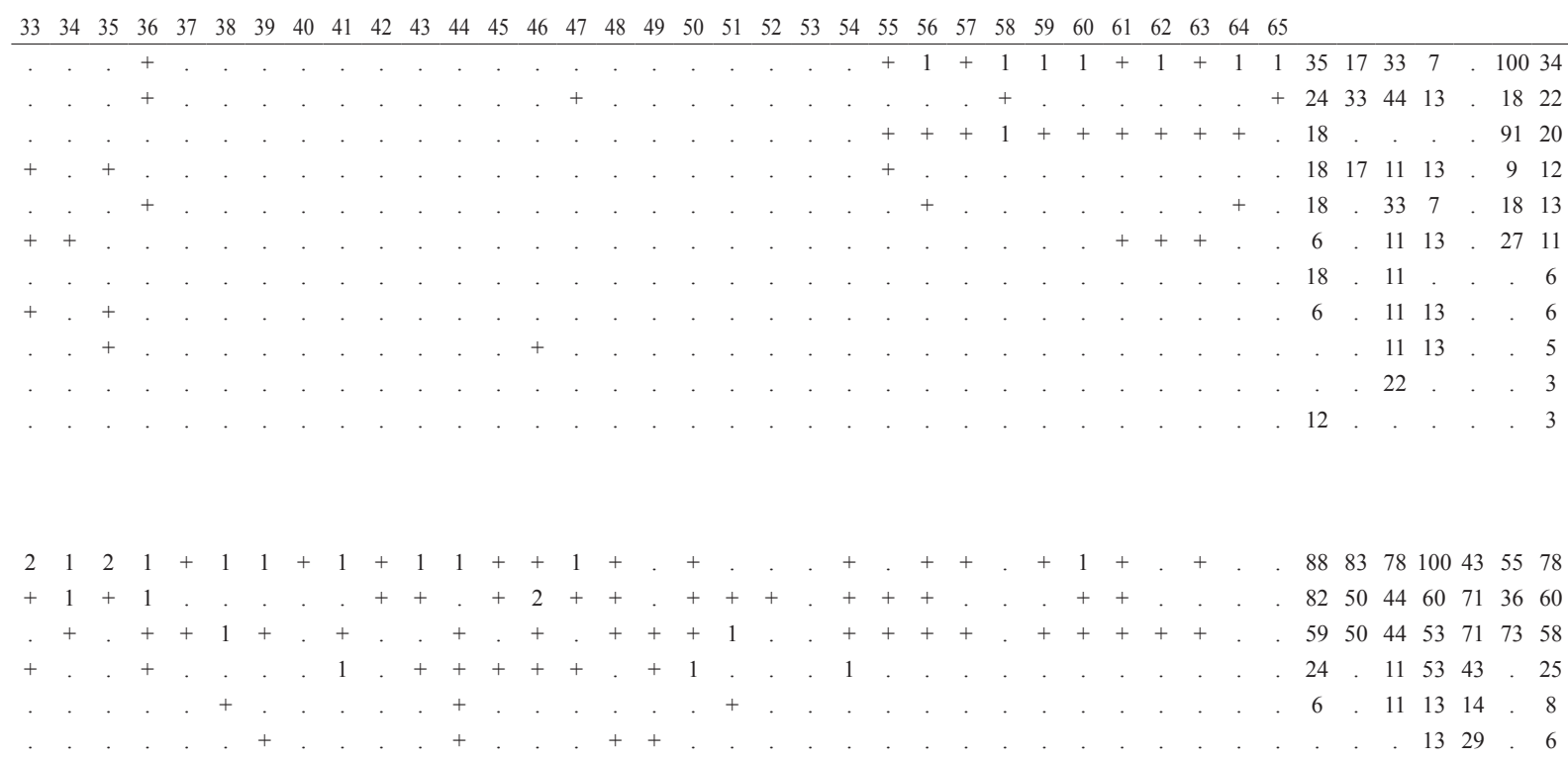

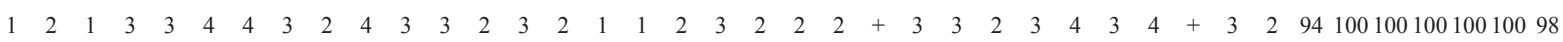

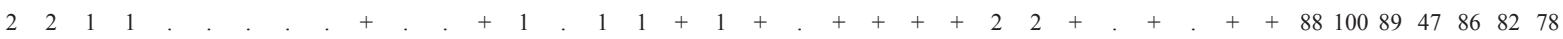

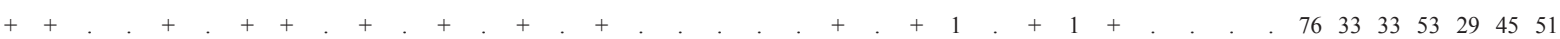

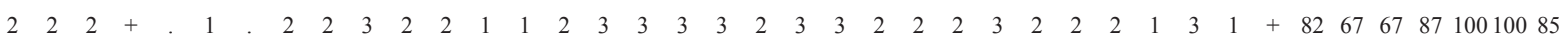

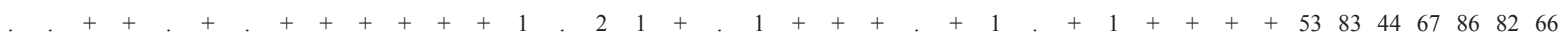

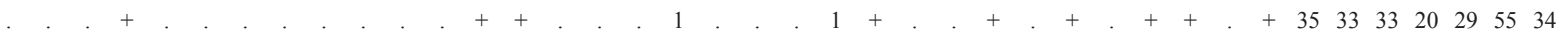

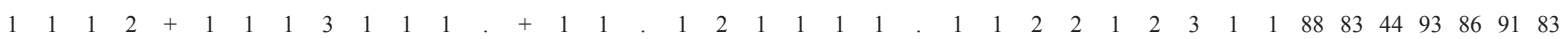

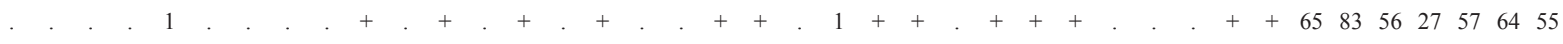

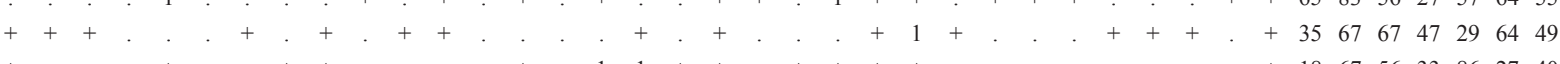

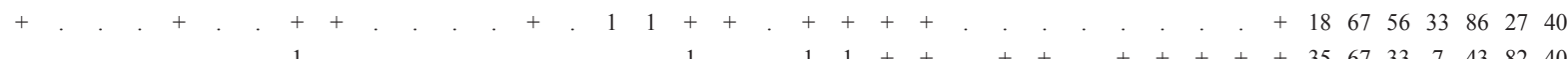

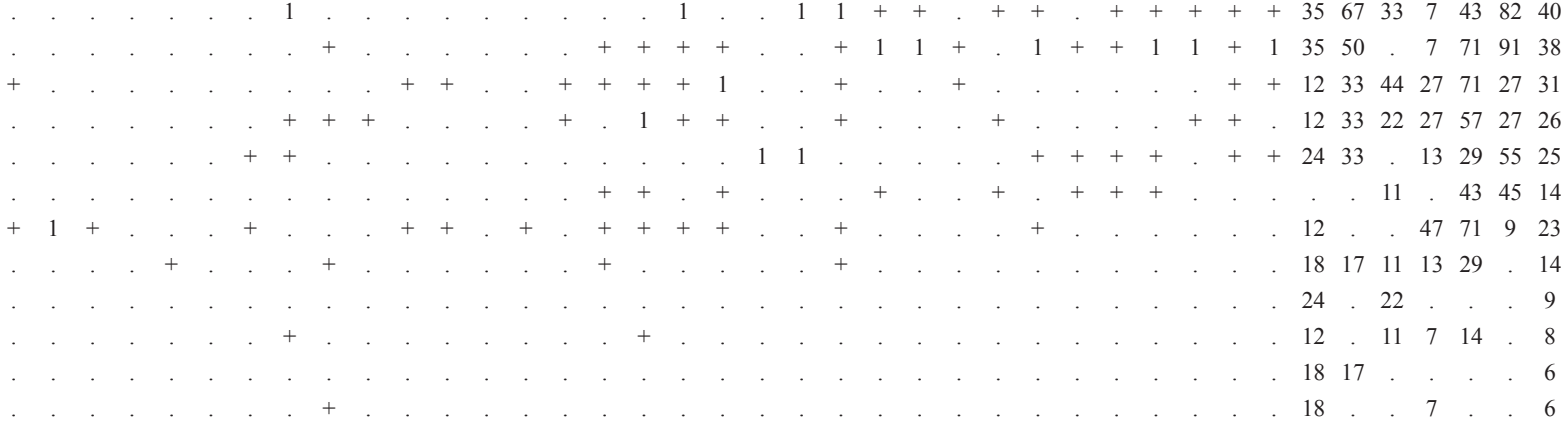

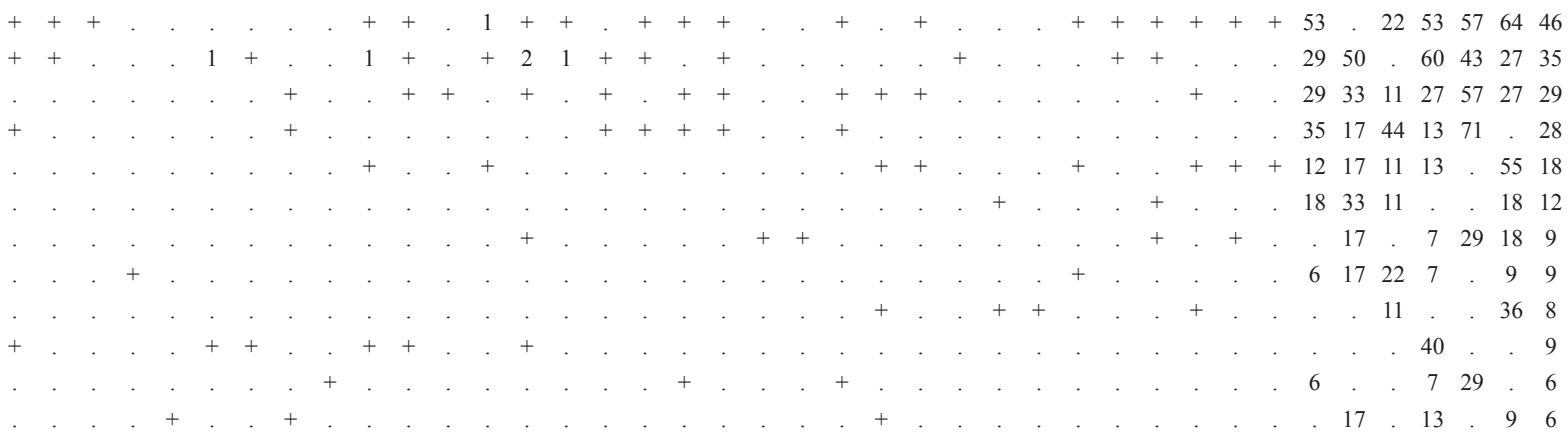


Relevé no. $\begin{array}{llllllllllllllllllllllllllllllll}1 & 2 & 3 & 4 & 5 & 6 & 7 & 8 & 9 & 10 & 11 & 12 & 13 & 14 & 15 & 16 & 17 & 18 & 19 & 20 & 21 & 22 & 23 & 24 & 25 & 26 & 27 & 28 & 29 & 30 & 31 & 32\end{array}$

Dactylorhiza maculata Asplenium trichomanes Cystopteris fragilis

Moehringia muscosa

Mooses and lichenes

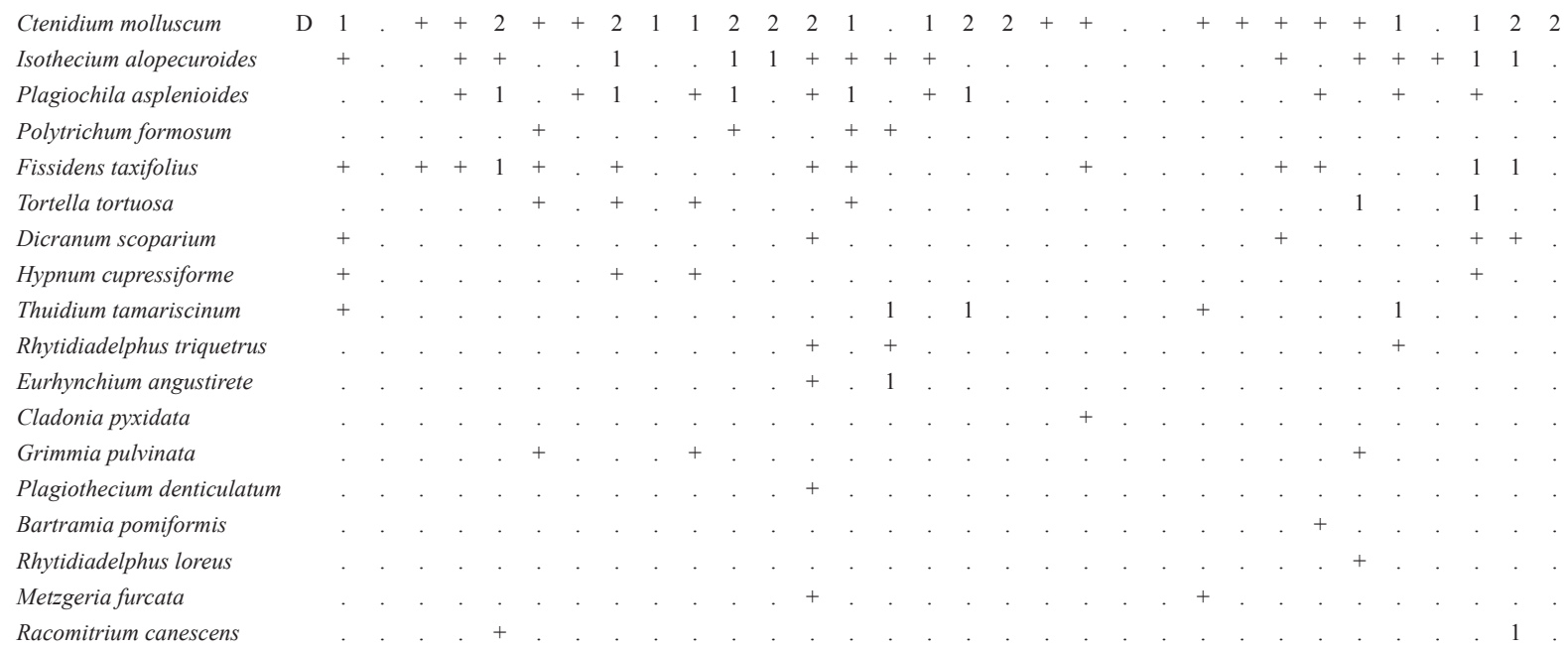

Appendix to Table 1:

Less frequent species: 1. Primula vulgaris $\mathrm{C}+$, Crataegus monogyna $\mathrm{B}+$, Rosa arvensis + , Rubus sp. + , Bromus ramosus $\mathrm{C}+$, 3. Betonica officinalis $\mathrm{C}+, 4$. Asarum europaeum $\mathrm{C}+, 6$. Calamintha grandiflora $\mathrm{C}+, 7$. Omphalodes verna $\mathrm{C}+, 8$. Rhamnus fallax $\mathrm{B}+$, Gymnocarpium robertianum $\mathrm{C}+$, Ostrya carpinifolia $\mathrm{B}+$, Cladonia rangiferina $\mathrm{D}+, 9$. Astrantia carniolica $\mathrm{C}+, 10$. Cicerbita alpina + , Vicia oroboides + , Poa nemoralis + , 13. Orthilia secunda $\mathrm{C}+, 15$. Lathyrus vernus $\mathrm{C}+$, Milium effusum + , Anomodon attenuatus D +, Sambucus racemosa $C+$, Dicranella heteromalla D +, 18. Polypodium vulgare C,+ 19 . Solanum dulcamara $\mathrm{C}+$, 20. Orthilia secunda $\mathrm{C}+$, Carex flacca + , 21. Sambucus racemosa $\mathrm{B}+$, Deschampsia cespitosa $\mathrm{C}+, 23$. Primula vulgaris $\mathrm{C}+$, Omphalodes verna + , 25. Polypodium vulgare $\mathrm{C}+$, Thalictrum aquilegiifolium $\mathrm{C}+$, 26. Euphorbia carniolica $\mathrm{C}+$, 27. Anomodon attenuatus $\mathrm{D}+, 28$. Convallaria majalis $\mathrm{C}+, 29$. Hedera helix $\mathrm{B}+, 31$. Leucobryum glaucum $\mathrm{D}+, 32$. Erica carnea $\mathrm{C}+$, 33. Phyllitis scolopendrium $\mathrm{C}+$, Aegopodium podagraria,+ 34 . Ulmus glabra $\mathrm{A}+, 36$. Rhamnus fallax $\mathrm{B}+$, Cladonia rangiferina $\mathrm{D}+$, Campanula trachelium $\mathrm{C}+, 37$. Ulmus glabra $\mathrm{A}+, 38$. Stellaria montana $\mathrm{C}+$, 39. Stellaria montana $\mathrm{C}+$, Galium rotundifolium $\mathrm{C} 1$, Atrichum undulatum $\mathrm{D}+, 40$. Clematis alpina $\mathrm{C}+, 43$. Veronica montana $\mathrm{C}+$, 46. Adenostyles alliariae 1 , Deschampsia cespitosa +, Poa nemoralis +, Crepis paludosa +, 47. Leucobryum glaucum D +, 48. Astrantia carniolica C +, 49. Ribes grossularia $\mathrm{B}+$, 50. Verbascum nigrum $\mathrm{C}+$, 51. Gymnocarpium robertianum $\mathrm{C}+$, Geranium sylvaticum + , Aconitum degenii subsp. paniculatum +, Anthriscus nitidus +, Neckera complanata D +, Rhizomnium punctatum +, 55. Calamintha grandiflora $\mathrm{C}+$, Knautia drymeia subsp. drymeia +, Viburnum lantana $\mathrm{B}+$, Melittis melissophyllum + , Astrantia carniolica + , Pteridium aquilinum + , 56. Berberis vulgaris $\mathrm{B}+, 58$. Veronica montana $\mathrm{C}+$, Crepis paludosa,+ 60 . Hypnum cupressiforme $\mathrm{D}+$, Polystichum braunii $\mathrm{C}+$, Lunaria rediviva + .

Localities of relevés: 1. Jezersko, between Roblek and Vršnik; 2. Lučka Bela; 3. Petrovo Brdo; 4. Kamniška Bistrica, under Žagana peč; 5. Petrovo Brdo, on the border of GG Kranj and GG Tolmin; 6. Zali Log, Plestenjak; 7. Zali Log; 8. Jezersko, between Kopišča and Ovča koča; 9. Jezersko, at the station of cabel railway upon Češka koča; 10. Matkov kot, dep. $139 a ; 11$. Kamniška Bistrica; 12. Jezersko, under Turni; 13. under Uršlja gora; 14. Železniki, Vancovec; 15. Petrovo Brdo, under Porezen; 16. Jelovica, $300 \mathrm{~m}$ western of Kališnik; 17. Jezersko, below the road under Mali vrh; 18. Zali Log, above Zadnja molža; 19, 20. Menina planina, Kerjavska peč; 21. Zali Log, border to GG Bled; 22. Jezersko, below the station of the cable railway to Češka koča; 23. Davča, Plestenjak; 24, 25, 26. Kamniška Bistrica, below Kuharjev vrh; 27. Menina planina; 28, 29. Menina planina, Kerjavska peč; 30. Zali Log, Črni vrh above Soriška planina; 31. Lučka Bela, Žegnani studenec; 32. Vancovec, below the hill 1000; 33. Jelendol; 34. Dobravlje, below Tolsti vrh; 35. Jelendol; 36. Vancovec, Železniki; 37. Menina planina, above Pesek towards hut; 38, 39. Menina planina, besides the road to the hut; 40. Dobrovlje, between Tolsti vrh and Šentjoški vrh; 41. Dražgoše, below Mili pogled; 42. Menina planina; 43 - 46. Menina planina; 47 Kamniška Bistica, below Žagana peč; 48 - 53. Jelendol; 54. Jelovica, below Jarčji vrh; 55 - 65. Logarska dolina. 

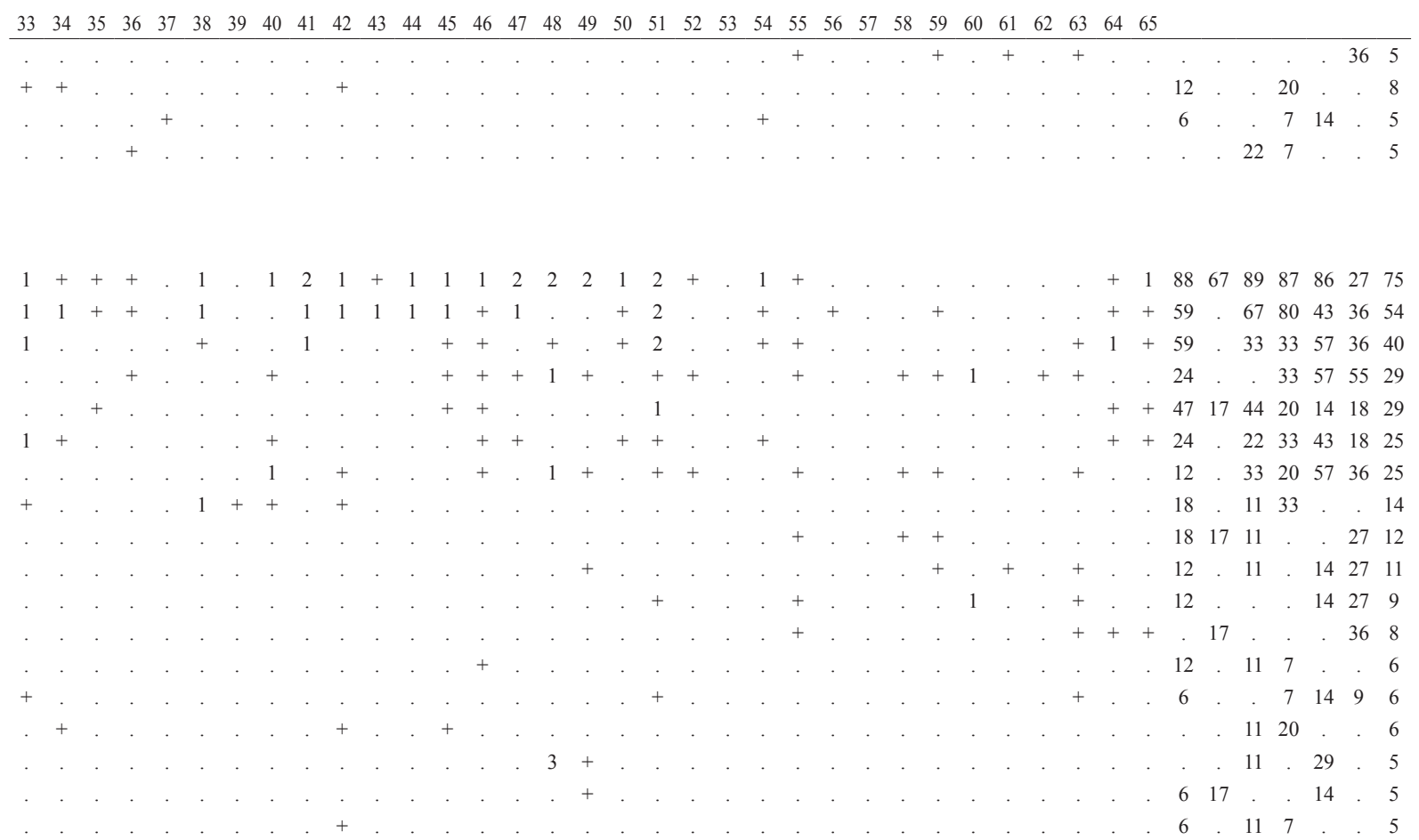